NBER WORKING PAPER SERIES

\title{
LONG-TERM CONSEQUENCES OF GROWING UP IN A RECESSION ON RISK PREFERENCES
}

\author{
Hitoshi Shigeoka
}

Working Paper 26352

http://www.nber.org/papers/w26352

\author{
NATIONAL BUREAU OF ECONOMIC RESEARCH \\ 1050 Massachusetts Avenue \\ Cambridge, MA 02138 \\ October 2019
}

This research utilizes the micro data from the Preference Parameters Study of Osaka University's 21st Century COE Program 'Behavioral Macro-Dynamics Based on Surveys and Experiments', its Global COE project 'Human Behavior and Socioeconomic Dynamics' and JSPS KAKENHI 15H05728 'Behavioral-Economic Analysis of Long-Run Stagnation.' I thank David Card, Takeshi Murooka, and Masayuki Yagasaki for their suggestions. All remaining errors are my own. The views expressed herein are those of the author and do not necessarily reflect the views of the National Bureau of Economic Research.

NBER working papers are circulated for discussion and comment purposes. They have not been peer-reviewed or been subject to the review by the NBER Board of Directors that accompanies official NBER publications.

(C) 2019 by Hitoshi Shigeoka. All rights reserved. Short sections of text, not to exceed two paragraphs, may be quoted without explicit permission provided that full credit, including (C) notice, is given to the source. 
Long-Term Consequences of Growing up in a Recession on Risk Preferences

Hitoshi Shigeoka

NBER Working Paper No. 26352

October 2019

JEL No. D81,J24,Z13

\begin{abstract}
$\underline{\text { ABSTRACT }}$
Risk preferences play a fundamental role in individuals' economic decision-making. We examine whether the historical macroeconomic environment shapes individuals' willingness to take risks. Using nationally representative samples from Japan and exploiting regional variation in economic conditions, we find that men who experienced severe economic conditions in youth are more risk averse in adulthood and the effect is long-lasting. In addition, those men are less likely to be selfemployed and they have longer tenure, which are consistent with elevated risk aversion. This study highlights the importance of experience at a critical period of life on the formation of risk preferences.
\end{abstract}

Hitoshi Shigeoka

Department of Economics

Simon Fraser University

8888 University Drive, WMC 4653

Barnaby, BC V5A 1S6

CANADA

and NBER

hitoshi_shigeoka@sfu.ca 


\section{Introduction}

This study investigates whether the historical macroeconomic environment shapes individuals' willingness to take risks. We rely on the well-grounded "impressionable years hypothesis” from socio-psychological literature, which suggests that individuals are highly susceptible to attitude change during late adolescence and early adulthood (Krosnick and Awin 1989). Based on this literature, we examine whether individuals differ in their willingness to take risks depending on the economic shocks they experienced at a critical period of life. Our main risk-aversion measure is based on hypothetical job choice questions: whether to take a safe job with guaranteed income or a risky job with a high chance of pay increases but a small chance of downward pay risk. In addition, we examine real-world labor market outcomes associated with risk aversion, such as self-employment.

Risk preferences play a fundamental role in individuals’ economic decision-making, such as saving, investment, consumption, and migration decisions. In standard economic models, it is assumed that individuals are endowed with stable risk preferences that do not change over time (Stigler and Becker 1977). A few recent studies have suggested that individuals who have experienced a financial crisis become risk averse (e.g., Necker and Ziegelmeyer 2016; Guiso et al. 2018). ${ }^{1}$ However, most of these studies investigate contemporaneous and short-term effects, but are silent on how long-lasting the effect is.

Our identification relies on regional variation in individual experience of economic shocks during impressionable years. Using information on each respondent's location during adolescence, we assign period- and location-specific economic shocks to the respondents. This identification strategy overcomes the challenge in that each cohort shares many experiences other than economic shocks, such as technological change. We include non-parametric age and year dummies, and a host of current as well as retrospective individual characteristics.

Our findings are summarized as follows. Using nationally representative samples from Japan, we find that men who are exposed to severe economic conditions during late adolescence

\footnotetext{
${ }^{1}$ In laboratory experiments, Cohn et al. (2015) document that adverse financial shocks make financial professionals more risk averse.
} 
show elevated risk aversion in adulthood. In particular, experiencing local economic shocks at least once during the ages of 18-21 years leads to a roughly 0.20 standard deviation (SD) increase in risk aversion in adulthood. The effect is persistent: we observe elevated risk aversion when men are well into their 30s and 40s. Since we find the same effect not only for college graduates but also for high school graduates, it is probably not only job-searching experience at the time of college graduation but the economic situation in general that drives our results. Importantly, the exposure to harsh economic conditions at any other age range has no impact on risk aversion, supporting the impressionable years hypothesis that susceptibility to attitude change is greatest during adolescence and early adulthood, and substantially decreases thereafter.

Our results are robust to several potential concerns. First, we verify that the results are not driven by particular cohorts. The findings are robust to the inclusion of cohort dummies in addition to age and year fixed dummies. Second, our results are robust to the inclusion of a number of life-cycle related variables. Finally, our results are robust to different ways of eliciting and constructing risk-aversion measures.

We also show that men who are exposed to severe economic conditions in late adolescence are less likely to be self-employed in adulthood, which is consistent with elevated risk aversion. The magnitude is substantial. Experiencing economic shocks during formative ages leads to as much as a 30\% reduction in self-employment once men have reached adulthood. This result suggests that a large negative economic shock can fundamentally alter an individual's risk preferences and thus, may have a long-lasting impact on an individual's decision-making in the real world.

This study is most related to Malmendier and Nagel (2011), which shows that early-life financial hardship is associated with conservative investment behavior in later life, whereas recent life events have the largest impact. The important difference is that while the results in Malmendier and Nagel (2011) are largely driven by beliefs rather than risk preferences, this study directly examines the risk preferences per se measured through hypothetical choice questions. This difference may explain why this study posits that experience at a critical period of life has a substantial impact on risk preferences while Malmendier and Nagel (2011) show 
that experience throughout history affects financial risk-taking behavior. Indeed, our results are consistent with Giuliano and Spilimberg (2014) which shows that the macroeconomic shocks during impressionable years affect preferences for redistribution in adulthood.

This study is related to a growing number of works suggesting that individuals' risk preferences can be altered by negative shocks, such as financial crises, conflict or violence, and natural disasters (for a recent review, see Chuang and Schechter, 2015). While the literature on the impact of non-financial negative shocks tends to produce mixed results regarding the direction of change in risk preferences (Schildberg-Hörisch 2018), studies on the impact of financial crisis are relatively more consistent: individuals who experience financial crisis become more risk averse. To the best of our knowledge, this is the first study that shows that experience at formative ages is of particular concern and that such experience has a long-lasting impact on the formation of risk preferences in adulthood.

More generally, recent economics literature suggests that the economic and cultural environment in which people grow up shapes their beliefs and attitudes, such as their trust in financial institutions (Guiso et al. 2004; Osili and Paulson 2008), stock market participation (Guiso et al. 2008), social policies (Alesina and Fuchs-Schundeln 2007), belief in the free market (Di Tella et al. 2007), belief about future returns from the stock (Malmendier and Nagel 2011), and preferences for redistribution (Luttmer and Singhal 2011; Giuliano and Spilimberg 2014). This study adds to the literature by showing that risk preference is also affected by the macroeconomic environment in which people grow up.

The rest of the paper is organized as follows. Section 2 describes the data, and Section 3 presents our econometric model. Section 4 reports our main findings on risk preferences, and Section 5 examines labor market outcomes. Section 6 concludes.

\section{Data}

The key variables for our analysis are historical economic shocks as explanatory variables and measures of risk preferences as dependent variables. We elaborate on each variable in detail in the following subsections. 


\subsection{Economic shocks}

In order to obtain the longest possible time series, we construct a measure of regional recessions using data on employment-to-job opening ratio at the prefecture level from the Ministry of Health, Labour and Welfare (MHLW) in Japan. ${ }^{2}$ The MHLW has provided monthly estimates of the employment-to-job opening ratio since 1963. To avoid the influence of World War II (WWII), we focus on cohorts born after 1945, the final year of WWII.

Our dependent variable for economic shock is a dummy that takes one if the individual experienced an economic shock for at least 1 year during his or her impressionable years. We define impressionable years from the ages of 18 to 21 years. According to the impressionable years hypothesis, individuals are highly susceptible to attitude change during late adolescence and early adulthood, which is roughly the ages of 18-25 years (Krosnick and Awin 1989). ${ }^{3}$ Giuliano and Spilimberg (2014) analyze the impact of macroeconomic shocks during the ages of 18-25 years on preferences for redistribution in adulthood. However, as shown in Figure A1, in Japan, the fraction of individuals who live in the same prefecture at the age of 15 years sharply drops by $25 \%$ at the age of 22 years, as many people graduate from college and start working in different locations. Therefore, we define impressionable years in this study as the ages of 18-21 years. We also show the results for a subset of individuals who stay in the same prefecture, and we show that other age ranges do not seem to influence the formation of risk preferences in adulthood.

Following Giuliano and Spilimberg (2014), we define an economic shock as a change in the employment-to-job opening ratio below the lowest $10^{\text {th }}$ percentile of the change in the employment-to-job opening ratio for Japan's 47 prefectures from 1963 to 2010. We later change the threshold to the $5^{\text {th }}$ percentile as a robustness check, and the results are robust with different thresholds.

\footnotetext{
${ }^{2}$ Giuliano and Spilimberg (2014) instead use change in the GDP growth rate. We do not use the GNP growth rate, as it captures only recessions related to the burst bubble in the early 1990s. The unemployment rate was not available at the regional level until recently. Furthermore, it is designed to capture the unemployment rate at the broader regional level (not prefecture level).

${ }^{3}$ See, for example, Spear (2000) for perspectives from literature on neurological development.
} 
Figure 1 displays the number of prefectures that experienced economic shocks from 1963 to 2010. There are three peaks: around the time of the oil crisis in 1973; in the early 1990s when the asset bubble burst; and around the time of the Great Recession in 2009. Appendix Figure A2 shows how often each prefecture experienced economic shocks. There is substantial regional variation in the labor market experiences of individuals living in different prefectures. For example, even though Akita (\#5) and Yamagata (\#6) are adjacent prefectures in the Tohoku region, Akita experienced no economic shocks during our sample period, while Yamagata experienced at least four.

\subsection{Measures of risk preferences}

Our primary dataset is the Japan Household Panel Survey on Consumer Attitudes and Satisfaction (JHPS-CPS), which is a nationally representative annual survey of Japan's resident population. ${ }^{4}$ The data are collected using self-administered paper questionnaires, which are hand-delivered to and picked up from the houses of participating households. ${ }^{5}$

Our measure of risk preferences is elicited from hypothetical questions. In particular, we have measures of risk preferences in two domains. The first is in the labor domain in which individuals decide whether to accept a job offer (hereafter, referred to as "labor"), and the second measure is in the finance domain in which individuals make a payment choice regarding the lottery (hereafter, referred to as “finance”). In each domain, we pick questions that are asked for at least 2 years from 2005-2011 in order to increase the statistical power. ${ }^{6,7}$

\footnotetext{
${ }^{4}$ Municipalities are classified into 40 stratums (10 geographical areas and 4 categories by population size). The unit of sampling spot in each stratum is the census unit and is selected by random systematic sampling.

${ }^{5}$ A JPY1,500 (US\$15) cash voucher is provided to all respondents for completing the survey.

${ }^{6}$ The JHPS-CPS was conducted in 2003-2016 (except for interruptions in 2014 and 2015). The first 2 years (2003-2004) were pilots and many different questions were asked compared to later years. We also do not use 2012 onwards, as Hanaoka et al. (2018) show that the Great Japan East Earthquake in 2011 altered people’s risk attitudes.

${ }^{7}$ While the same individuals answer the same questions across years, the correlation of responses between different years is quite low. For example, for the Labor1 question, the correlation in responses in the first and second years is only 0.33 . This number is close to the case of the Health and Retirement Study, which reports correlation of 0.27 (Kimball et al. 2008).
} 
Our main risk-aversion measures are those in the labor domain. We also examine the riskaversion measures in the finance domain to assess whether individuals who are risk averse in the labor domain are also risk averse in another domain. If so, the economic shocks in the impressionable years may have far-reaching consequences on the risk preferences of those who are affected.

In the labor domain, respondents choose between a safe job and a risky job in hypothetical scenarios. The Health and Retirement Study asks a variant of this question to measure risk preferences (e.g., Barsky et al. 1997; Kimball et al. 2008; Sahm 2012). We illustrate one example from three labor-domain risk measures here.

With equal chances, a risky job doubles monthly income or cuts it by a specific fraction (downside risk). Varying the downside risk of monthly income in subsequent questions refines the measure of risk preferences.

Specifically, in 2005-2011, the JHPS-CPS poses the following scenario. Which of the following two jobs do you prefer? Assume that the job contents are the same. The first is a job that gives you a 50-50 chance of doubling your monthly income and a 50-50 chance of cutting your monthly income by $30 \%$. The second is a job that will increase your monthly income by $5 \%$.

On one hand, individuals who accept the risky job then consider a choice between two jobs, one with even higher downside risk, as follows.

The first is a job that gives you a 50-50 chance of doubling your monthly income and a 50-50 chance of cutting your monthly income by 50\%. The second is a job that will increase your monthly income by $5 \%$.

On the other hand, those who initially decline the risky job then consider a choice between two jobs, one with even lower downside risk.

The first is a job that gives you a 50-50 chance of doubling your monthly income and a 50-50 chance of cutting your monthly income by $10 \%$. The second is a job that will increase your monthly income by $5 \%$.

The other two questions in the labor domain vary either the amount of increases in monthly 
income for the risky job or the probability of downside risks for the risky job. Appendix B shows the exact formats of the other two questions in the labor domain. The three questions in the labor domain are labeled Labor1, Labor2, and Labor3.

The upper half of Appendix Figure A3 displays the distribution of choices. The higher the number, the more risk averse the choice is. For all the questions, the fraction of respondents who choose the most risk-averse choice (\#4) — individuals who decline both risky jobs, and always choose the safe job with guaranteed income amount—is the highest. Therefore, our risk-averse measure is a dummy variable that takes one for the most risk-averse choice. As a robustness check, we convert the hypothetical choices into the risk-aversion parameter $(\gamma)$ by assuming a constant relative risk aversion (CRRA) function following Kimball et al. (2008). ${ }^{8}$ The results are robust even if we convert our ordinal measure of risk preferences into a cardinal measure, like $\gamma$. In addition, the results are robust to ordered logit, in which the ordered choices are used as outcomes (both results are shown later).

In the finance domain, the JHPS-CPS asks respondents about their willingness to pay for a hypothetical lottery. This approach to elicit risk preferences is also adopted in the past literature (e.g., Cramer et al. 2002; Hartog et al. 2002; Guiso and Paiella 2008).

We illustrate one of the three risk-aversion measures in the finance domain here (Finance1). There is a 1\% chance that the lottery wins JPY100,000 (US\$1,000) and nothing otherwise. Respondents are asked whether they would buy this lottery at a price of JPY200 (\$US2). Varying the purchase price of the lottery refines the measure of risk preferences.

Specifically, in 2005-2008, the JHPS-CPS poses the following scenario. There is a lottery with a 1\% chance of winning JPY100,000 and nothing otherwise. Would you buy this lottery at a price of JPY200?

Individuals stating that they would buy the lottery at this price then consider higher prices while those initially stating that they would not buy it then consider lower prices. The lower the

\footnotetext{
${ }^{8}$ Specifically, we assume a CRRA utility function, $U(W)=\frac{W^{1-1 / \theta}}{(1-1 / \theta)}$, where the coefficient of relative risk tolerance $\theta=-U^{\prime} / w U^{\prime \prime}$ may differ across individuals. We examine relative risk aversion $\gamma$, which is $1 / \theta$.
} 
price individuals accept, the more risk averse they are.

The second question in the finance domain (Finance2) varies the amount of winning the lottery (JPY2,000) and the probability of winning (50\%). The third question in the finance domain (Finance3) instead asks respondents whether they would sell the lottery at this price, assuming that the individual already possessed the lottery. Appendix B shows the exact formats of the other two questions in the finance domain.

The lower half of Appendix Figure A3 shows the distribution of choices. The higher the number, the more risk averse the choice is; that is, individuals are willing to pay less (or sell at the low price). To be consistent with the risk-aversion measures in the labor domain, the riskpreference measure in the finance domain is also a dummy that takes one for the most risk-averse choice. As robustness checks, we examine ordered logit, and convert the choices into riskaversion parameters. ${ }^{9}$

To make each risk measure comparable, we standardize each measure by subtracting the mean and dividing by the SD so that each has a mean of zero and an SD of one. We later show that raw data without standardization deliver qualitatively the same results.

Appendix Table A1 provides summary statistics. Our cohorts are born between 1946 and 1989. The average age is 47 years. Slightly more than half (53\%) is low educated (less than a college degree), while $93 \%$ is employed, and $13 \%$ is self-employed.

\subsection{Validity of risk-aversion measures}

One concern of self-reported risk-aversion measures based on a non-incentivized and hypothetical question is whether they indeed reflect an individual's underlying risk traits. Many studies show that risk measures obtained through hypothetical survey questions are reliable predictors of actual risk-taking behavior (e.g., Barsky et al. 1997; Donkers et al. 2001; Anderson

\footnotetext{
${ }^{9}$ We define the reservation price as the midpoint of the two prices at which respondents switch choices. Following Cramer et al. (2002), we simply transform the reservation price $(\lambda)$ to a measure of risk aversion: $=$ $1-\lambda / \mathrm{E}(X)$ where $\mathrm{E}(X)$ is the expected value of the lottery $X$ (e.g., $\mathrm{E}(X)$ equals JPY1,000 for Labor1). Note that the higher the number is, the more risk averse the respondent is.
} 
and Mellor 2008; Guiso and Paiella 2008; Dohmen et al. 2011).

To verify the validity of our risk measures, we run various tests. First, Appendix Table A1 shows that six different measures are positively correlated. In particular, they are strongly positively correlated within the same domain $(0.67-0.75$ in the labor domain, and $0.28-0.70$ in the finance domain). Second, our risk measures tend to be correlated in expected ways with classical covariates of risk preferences. For example, men are less risk averse than women, as documented in Croson and Gneezy (2009) (not shown). Third, we document that our measures have predictive power for individuals’ risk-taking behavior. Appendix Table A2 shows that our indicators for risk aversion are strongly negatively correlated with gambling (a dummy variable equal to one if an individual gambles more than twice a week), possession of a financial asset (a dummy variable equal to one if an individual owns stocks and corporate bonds in her/his portfolio), and rare wear of seatbelts (a dummy variable equal to one if an individual does not wear or rarely wears a seatbelt).

\section{Econometric model}

We focus on men, as the employment rate for women in our sample is as low as $67 \%$ while that for men is $93 \%$. As we attribute the labor market experience in late adolescence to risk preferences in adulthood, the inclusion of women with a low employment rate would introduce substantial measurement errors. ${ }^{10}$

Our baseline specification is very similar to that of Giuliano and Spilimberg (2014):

$$
\begin{gathered}
\text { Risk }_{\text {ipt }}=\alpha_{0}+\alpha_{1} \text { Economic shock }_{p 15, \text { imp.years }}+\alpha_{2} X_{i}+\beta_{a}+\gamma_{p}+\delta_{t}+\theta_{p 15}+\theta_{p 15} * \\
\text { age }+\varepsilon_{\text {ipt }},
\end{gathered}
$$

where Ris $_{\text {ipt }}$ is the risk-aversion parameter for individual $i$ in prefecture $p$ surveyed at time $t$. Economic shock $k_{\text {15,imp.years }}$ is a dummy that equals one if an individual experiences an economic shock during the impressionable years in his/her prefecture of residence at the age of 15 years asked in the JHPS-CPS, which we use as a reference prefecture for the whole of the

10 The results for women are available in Appendix Table A14. 
ages of 18-21 years. $X_{i}$ is a vector of individual characteristics, namely, marital status, employment status, and non-parametric dummies for age, education, and household income. We also include information on the family background of the individual at the age of 15 years in some specifications.

The specifications include fixed effects for age, year, prefecture of residence at the age of 15 years, and prefecture of current residence. Age fixed effects $\left(\delta_{a}\right)$, and year fixed effects $\left(\delta_{t}\right)$ control the age-specific trend of risk preferences, and common shocks at the national level, respectively. Prefecture of residence at the age of 15 years $\left(\theta_{p 15}\right)$, and prefecture of current residence $\left(\gamma_{p}\right)$ control for the prefecture-specific risk aversion that could affect difference in risk preferences (e.g., culture) both at the origin and later, respectively. We also include interaction of prefecture at the age of 15 years fixed effects with linear in age $\left(\theta_{p 15} * a g e\right)$ to help rule out the possibility that our results are driven by prefecture-specific cohort effects. For example, experience of earthquakes can differentially affect the risk preferences of different cohorts (Hanaoka et al. 2018).

We estimate equation [1] and its variant by ordinary least squares for ease of interpretation, but qualitatively similar results are obtained with ordered logit, as shown later. Standard errors are clustered at the prefecture of residence at the age of 15 years.

The main concern for our identification strategy is omitted variable bias. We consider four different types of potential bias, and we account for each as follows. First, our main explanatory variable, Economic shock $k_{p 15, i m p . y e a r s}$, consists of two variations: variation across regions and variation between cohorts. To control for cohort-specific effects, in the first robustness check, we include each cohort dummy. For example, different education policies may have different impacts on the formation of risk preferences for different cohorts. Second, our results could be driven by prefecture-specific trends. In the second robustness check, we include a full set of interactions between prefecture of survey and survey year to consider all possible prefecture-ofresidence and time-varying covariates. 
Third, our source of identification is that each prefecture experiences different economic shocks over time. Since an economic shock is the only regressor that is time-varying at the prefecture level during impressionable years, the concern is that it captures any other timevarying prefecture factors. Inclusion of prefecture at the age of 15 years interacted with age linear trend in all specifications partially mitigates this concern. Furthermore, in one of the robustness checks, we include gross national product (GNP) per capita, which is prefecturespecific time-varying controls. In this specification, our results capture the effect of the economic shocks net of the overall macroeconomic level in the region. Fourth, while we exclude cohorts born before the end of WWII, we nonetheless include war-related variables interacted with each cohort to account for any influences of the war on the formation of risk preferences.

\section{Results}

In Table 1, we report the results for risk preference in the labor domain (columns 1-3) and those in the finance domain (columns 4-6). We also report the estimated average effect size (AES) coefficients (columns 7-9). Following Kling and Liebman (2004), AES is computed as follows. Let $\beta_{k}$ and $\sigma_{k}$ indicate the estimated coefficient and its SD for the outcome variable $k$. Then, the AES is equal to $\frac{1}{K} \sum_{k=1}^{K} \frac{\beta_{k}}{\sigma_{k}}$, where $K$ is the total number of outcome variables. Since we already standardize each outcome, AES, in this case, is equivalent to the simple average of each estimated coefficient.

AES estimates have two advantages of reducing both Type I and Type II errors. On the one hand, summary as an index reduces the possibility that the estimated coefficients are statistically significant due to chance (Type I error), which is more likely to occur with a single outcome measure. On the other hand, it reduces the error of weak statistical power (Type II error). We report three set of AES estimates: one for risk preferences in the labor domain (the three measures for risk preference in the labor domain combined); one for risk preferences in the finance domain (the three measures for risk preference in the finance domain combined); and one for all six variables together. 


\subsection{Main results}

Table 1 reports the estimates from the baseline specification [1]. Columns (1)-(3) report the estimates on risk preferences in the labor domain, which are our main outcomes of interest. We code outcome in such a way that positive coefficients indicate elevated risk aversion. All columns (1)-(3) show that individuals who experience an economic shock during impressionable years are less likely to take the risk of changing jobs with potential high pay but some downward risk. The estimates are statistically significant at the $1 \%$ level for Labor1, and Labor3, and at the $5 \%$ level for Labor2. In terms of magnitude, AES in column (7) indicates that experiencing an economic shock during adolescence reduces the chance of taking new job opportunities by 0.18 $\mathrm{SD}(\mathrm{p}<0.01)$. This result indicates that experiencing an economic shock during formative years has a persistent negative effect on risk preferences in the labor domain in adulthood.

Columns (4)-(6) of Table 1 show that those who experience an economic shock in impressionable years are less likely to take risks in the financial domain too. While the results are slightly weaker than those for the labor domain—which is plausible, as our economic shocks are based on labor shocks - two out of three measures are statistically significant at the $5 \%$ level. Column (8) shows that the magnitude of AES for the finance domain is two-thirds that for the labor domain $(\mathrm{p}<0.05)$. These results suggest that even though economic shock is defined by labor market outcomes, respondents exposed to negative economic shocks exhibit risk aversion not only in the labor domain but also in another domain. Column (9), which takes the six variables together, shows roughly a $0.15 \mathrm{SD}$ increase in risk preferences $(\mathrm{p}<0.05)$.

\subsection{Robustness checks}

We subject the results in Subsection 4.1 to a series of other robustness checks. Table 2 summarizes these results. To save space, we present only the results for AES for all six variables hereafter. The full results for each column of Table 2 are presented in Appendix Tables A3-A9. For ease of comparison, column (1) replicates the baseline results from column (9) of Table 2. 
Column (2) of Table 2 adds cohort dummies to baseline specifications. The estimate is slightly larger than the baseline estimate (0.172 vs. 0.151). Column (3) further adds all interactions between the prefecture of survey and year effects as well as the two series of nonparametric dummies for father's and mother's education at the age of 15 years. Column (3) is the most stringent specification. The results are almost identical to those of column (2). Column (4) restricts the sample to non-movers, whose current prefecture is identical to the prefecture at the age of 15 years. While the sample size shrinks, the estimates remain statistically significant at the $5 \%$ level.

The major concern in our identification strategy is that economic shock is the only timevarying variable. Thus, we are afraid that it may capture something other than economic shock specific to the prefecture at that time, which is correlated with risk aversion. To mitigate the concern, we control the prefecture-level time-varying GNP per capita during impressionable years in column (5). This specification identifies the effect of experiencing a severe economic condition net of the level of the macroeconomic environment. We find that estimated coefficients are rarely affected, suggesting that experiences of economic shocks (i.e., change) instead of the overall macroeconomic level drive our results.

While we focus only on cohorts born after WWII to mitigate the impact of war on risk aversion, we include two war-related variables. Specifically, we interact the cohort fixed effects with the number of deaths and missing people per capita, and the number of buildings collapsed per capita due to WWII. ${ }^{11}$ Column (6) shows that our results are robust to the inclusion of warrelated variables.

We define economic shock as a change in employment-to-job opening ratio below the lowest $10^{\text {th }}$ percentile of the change in employment-to-job opening ratio for Japan's 47 prefectures from 1963 to 2010. Column (7) changes the threshold to the $5^{\text {th }}$ percentile, but the results are robust with different thresholds.

Appendix Tables A10-A12 present other robustness checks, and our results are quite

${ }^{11}$ We thank David Weinstein for sharing the data with us. 
robust to different ways of defining outcomes or different estimation techniques. Appendix Table A10 shows the results before outcomes are standardized. Appendix Table A11 shows the results when risk choices are converted to cardinal measures. Finally, Appendix Table A12 shows the results of the ordered logit specifications.

Thus far, we follow the socio-psychology (and also neuroscience) literature and focus on the effect of impressionable years on the formation of risk preferences (e.g., Krosnick and Awin 1989). Here, we examine whether other age ranges have any impact on risk preferences in adulthood. Table 3 shows the results for other age ranges. We repeat our baseline specification (equation [1]) based on different 4-year range intervals $(2-5,6-9, \ldots$ and $50-53) .{ }^{12}$ It is reassuring that none of the other age ranges has any meaningful impact on the formation of risk preferences. ${ }^{13}$ In addition, the magnitudes of the estimated coefficients are economically small compared to our main findings in Table 1.

\subsection{Heterogeneity}

We also examine heterogeneity by individual characteristics. The results are presented in Table 4. Columns (1) and (2) examine heterogeneity by educational level. We find that while the estimates for high-educated respondents are slightly larger than those for low-educated respondents, the difference is not statistically significant. In Japan, the ages of 18-21 years correspond to years spent in college. Thus, those who are low-educated (less than college) are already working, while those who are high-educated (more than college) are not likely to be working yet. It is reassuring that we find the same effect for both education segments, suggesting that it is probably not only job-searching experience at the time of college graduation but the economic situation in general that drives our results. ${ }^{14}$ We also examine heterogeneity by

\footnotetext{
12 Since the JHPS-CPS asks for prefecture residence at the age of 15 years only, the measurement error becomes larger as the other age ranges deviate from 15 years.

13 See Appendix Table A13 for full estimates for each risk-aversion outcome.

14 Our results are robust to excluding the age of 21 years, which is the typical age 1 year before college graduation, from the impressionable years (results are available upon request).
} 
maternal education. Columns (3) and (4) show that individuals whose mothers are low educated (less than high school) have double the impact than those whose mothers are highly educated. ${ }^{15}$ Columns (5) and (6) show that low-income respondents are more affected by economic shock than high-income respondents.

Finally, we examine the effect by age in columns (7)-(10) of Table 4. We find significant effects in the age range of the 30s and 40s, suggesting that the experience of formative years on risk preferences is persistent. These age ranges roughly correspond to cohorts who experienced the oil crisis of 1973, and the burst asset bubble of the early 1990s.

\section{Labor market outcomes}

One potential explanation for our finding is that individuals who experience tough economic situations themselves suffer in the job market and currently have low-paying jobs or are unemployed. It is known that graduating during a recession leads to large initial earnings losses in Japan (Genda et al. 2010). ${ }^{16}$ We account for such endowment effects by controlling for employment status, full sets of education, and income dummies in equation [1]. Furthermore, our results are not only driven by college graduates seeking work at the age of 21 years the year before graduating from college.

Nonetheless, we directly consider the labor market outcomes in this section. In this specification, to avoid endogeneity, we modify equation [1] by including only marital status, and full sets of education dummies as demographic controls (i.e., no income or employment status included). The results are presented in Table 5.

Column (1) in Table 5 shows that the probability of employment is not different. Columns (2) and (3) show no difference in hours worked and slightly higher income rather than lower income. Columns (4) and (5) show that firm size and industry are also not statistically different. Interestingly, men who experienced severe economic shocks at the ages of 18-21 years are less likely to be self-employed (p-value<0.01). Since more risk-averse individuals are less likely

\footnotetext{
${ }^{15}$ We obtain very similar results using the father's education.

${ }^{16}$ See also the literature in the US (e.g., Kahn 2010; Oreopoulos et al. 2012).
} 
to be self-employed (Dohmen et al. 2011), our results are consistent with elevated risk aversion. The magnitude is substantial. Since the mean of the outcome is $12.6 \%$, the magnitude of the coefficients (0.037) indicates a 30\% decline in self-employment among those men.

In addition, the tenure of the men is slightly longer, suggesting that men do not change jobs. In particular, once we exclude the self-employed, those who grow up in recessions in impressionable years have roughly 1-year longer tenure, which corresponds to a $6.2 \%$ increase from the mean.

Taken together, these results indicate that exposure to a tough economic condition during formative years has far-reaching consequences for labor market outcomes. Not only are those men risk averse in hypothetical job scenarios, but indeed they are less likely to be self-employed and have longer tenure, suggesting that they do not want to take risks in the real labor market.

\section{Conclusion}

This study demonstrates that the historical macroeconomic environment shapes individuals’ willingness to take risks. We show that men who experience severe economic conditions in late adolescence show higher aversion to taking risks in adulthood. The effect is long-lasting. In addition, we show that those men are less likely to be self-employed and they have longer tenure, which are consistent with elevated aversion toward taking risks. This study highlights the importance of experience in critical years of life on the formation of risk preferences. While our results are not driven by differences in endowment or other time-varying regional characteristics, investigating the underlying mechanism (e.g., fear in switching jobs) is left as an avenue for future research.

\section{References}

Alesina, Alberto, and Nicola Fuchs-Schundeln. (2007) "Good-bye Lenin (or Not?): The Effect of Communism on People's Preferences.” American Economic Review 97: 1507-1528.

Anderson, Lisa R., and Jennifer M. Mellor. 2008. "Predicting health behaviors with an experimental measure of risk preference.” Journal of Health Economics 27(5): 1260-1274. 
Barsky, Robert B., F. Thomas Juster, Miles S. Kimball, and Matthew D. Shapiro. 1997. "Preference Parameters and Behavioral Heterogeneity: An Experimental Approach in the Health and Retirement Study.” Quarterly Journal of Economics 112(2): 537-579.

Chuang, Yating, and Laura Schechter. 2015. "Stability of experimental and survey measures of risk, time, and social preferences: A review and some new results.” Journal of Development Economics 117: 151-170.

Cohn, Alain, Jan Engelmann, Ernst Fehr, and Michel Andre Marechal. 2015. "Evidence for Countercyclical Risk Aversion: An Experiment with Financial Professionals.” American Economic Review 105(2): 860-885.

Cramer, Jan S., Joop Hartog, Nicole Jonker, and C. Mirjam Van Praag. 2002. "Low risk aversion encourages the choice for entrepreneurship: An empirical test of a truism." Journal of Economic Behavior and Organization 48(1): 29-36.

Croson, Rachel, and Uri Gneezy. 2009. “Gender Differences in Preferences.” Journal of Economic Literature 47(2): 448-474.

Di Tella, Rafael, Sebastian Galiant, Ernesto Schargrodsky. 2007. "The Formation of Beliefs: Evidence from the Allocation of Land Titles to Squatters.” Quarterly Journal of Economics 122: 209-241.

Dohmen, Thomas, Armin Falk, David Huffman, Uwe Sunde, Jurgen Schupp, and Gert G. Wagner. 2011. "Individual Risk Attitudes: Measurement, Determinants, and Behavioral Consequences.” Journal of the European Economic Association 9(3): 522-550.

Donkers, Bas, Bertrand Melenberg, and Arthur Van Soest. 2001. "Estimating Risk Attitudes using Lotteries: A Large Sample Approach.” Journal of Risk and Uncertainty 22(2): 165295.

Genda, Yuji, Ayako Kondo, and Souichi Ohta. 2010. "Long-Term Effects of a Recession at Labor Market Entry in Japan and the United States.” Journal of Human Resources 45: 157196.

Giuliano, Paola, and Antonio Spilimbergo. 2014. “Growing up in a Recession.” The Review of Economic Studies 81(2): 787-817.

Guiso, Luigi, and Monica Paiella. 2008. "Risk Aversion, Wealth, and Background Risk.” Journal of the European Economic Association 6(6): 1109-1150.

Guiso, Luigi, Paola Sapienza, and Luigi Zingales. 2004. "The Role of Social Capital in Financial Development.” American Economic Review 94: 526-556.

Guiso, Luigi, Paola Sapienza, and Luigi Zingales. 2008. “Trusting the Stock Market.” Journal of Finance 63: 2557-2600.

Guiso, Luigi, Paola Sapienza, and Luigi Zingales. 2018. “Time Varying Risk Aversion.” Journal of Financial Economics 128(3): 403-421.

Hanaoka, Chie, Hitoshi Shigeoka, and Yasutora Watanabe. 2018. "Do Risk Preferences Change? Evidence from the Great East Japan Earthquake.” American Economic Journal: Applied Economics 10(2): 298-330.

Hartog, Joop, Ada Ferrer-i-Carbonell, and Nicole Jonker. 2002. "Linking Measured Risk Aversion to Individual Characteristics.” Kyklos 55(1): 3-26.

Lisa B. Kahn. 2010. “The long-term labor market consequences of graduating from college in a 
bad economy.” Labour Economics 17(2): 303-316.

Luttmer, Erzo F. P., and Monica Singhal. 2011. "Culture, Context, and the Taste for Redistribution.” American Economic Journal: Economic Policy 3(1): 157-179.

Kimball, Miles S, Claudia R Sahm \& Matthew D Shapiro. 2008. "Imputing Risk Tolerance From Survey Responses.” Journal of the American Statistical Association 103(483): 10281038.

Kling, Jeffrey, and Jeffrey Liebman. 2004. "Experimental Analysis of Neighborhood Effects on Youth." http://www.nber.org/mtopublic/483.pdf.

Krosnick, Jon. A., and Duane. F. Alwin. 1989. "Aging and susceptibility to attitude change.” Journal of Personality and Social Psychology, 57(3): 416-425.

Malmendier, Ulrike, and Stefan Nagel. 2011. "Depression Babies: Do Macroeconomic Experiences Affect Risk Taking?” Quarterly Journal of Economics 126(1): 373-416.

Necker, Sarah, and Michael Ziegelmeyer. 2016. "Household risk taking after the financial crisis." Quarterly Review of Economics and Finance 59: 141-160.

Oreopoulos, Philip, Till von Wachter, Andrew Heisz. 2012. "The Short- and Long-Term Career Effects of Graduating in a Recession.” American Economic Journal: Applied Economics 4(1): 1-29.

Osili, Una Okonkwo, and Anna L. Paulson. 2008. "Institutions and Financial Development: Evidence from International Migrants in the United States." Review of Economics and Statistics 90: 498-517.

Sahm, Claudia R. 2012. “How Much Does Risk Tolerance Change?” Quarterly Journal of Finance 2(4): Article 5.

Schildberg-Hörisch, Hannah. 2018. “Are Risk Preferences Stable?” Journal of Economic Perspectives 32(2): 135-154.

Spear, Linda Patia. 2000. "Neurobehavioral Changes in Adolescence.” Current Directions in Psychological Science 9(4): 111-114.

Stigler, George J., and Gary S. Becker. 1977. “De Gustibus Non Est Disputandum.” American Economic Review 67(2): 76-90. 


\section{Figure 1}

\section{Economic shocks}

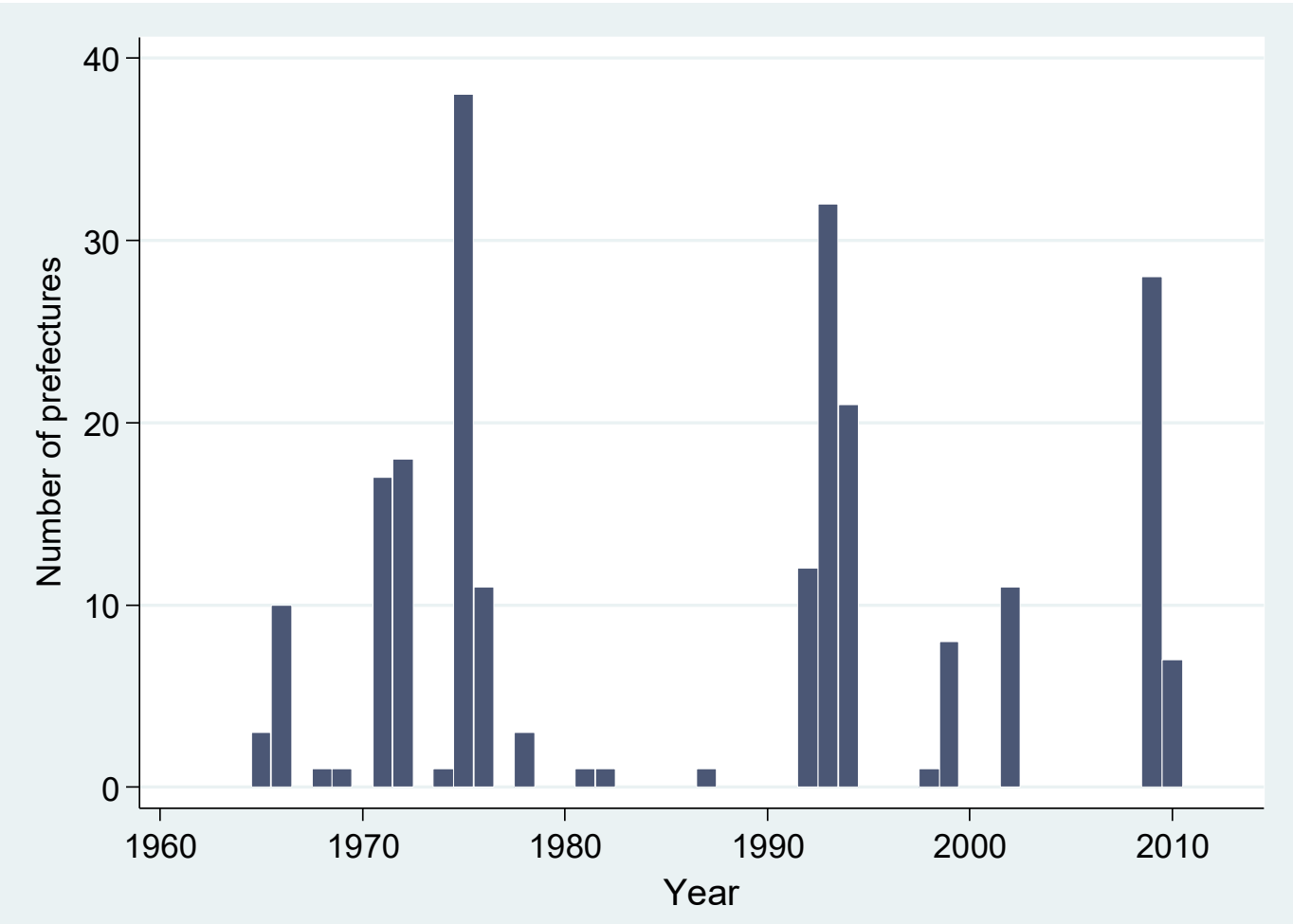

Notes: The figure display the number of prefectures that experience the economic shocks. There are three peaks: around the time of the oil crisis in 1973; in the early 1990s when the asset bubble burst; and around the time of the Great Recession in 2009. There is a total of 47 prefectures in Japan. 


\section{Table 1}

\section{Main results}

\begin{tabular}{|c|c|c|c|c|c|c|c|c|c|}
\hline & $(1)$ & $(2)$ & (3) & (4) & $(5)$ & (6) & (7) & $\overline{~(8)}$ & (9) \\
\hline & Labor1 & Labor2 & Labor3 & Finance1 & Finance2 & Finance3 & $\begin{array}{c}\text { AES } \\
\text { Labor }\end{array}$ & $\begin{array}{c}\text { AES } \\
\text { Finance }\end{array}$ & $\begin{array}{c}\text { AES } \\
\text { All }\end{array}$ \\
\hline Economic shock & $\begin{array}{c}0.117 * * * \\
(0.036)\end{array}$ & $\begin{array}{c}0.122 * * \\
(0.046)\end{array}$ & $\begin{array}{c}0.296 * * * \\
(0.102)\end{array}$ & $\begin{array}{c}0.145 * * \\
(0.068)\end{array}$ & $\begin{array}{c}0.055 \\
(0.073)\end{array}$ & $\begin{array}{c}0.154 * * \\
(0.069)\end{array}$ & $\begin{array}{c}0.178 * * * \\
(0.045)\end{array}$ & $\begin{array}{c}0.124 * * \\
(0.053)\end{array}$ & $\begin{array}{c}0.151 * * * \\
(0.037)\end{array}$ \\
\hline R-squared & 0.09 & 0.10 & 0.16 & 0.09 & 0.11 & 0.09 & & & \\
\hline $\mathrm{N}$ & 7,749 & 6,361 & 1,428 & 3,156 & 3,159 & 3,134 & 5,179 & 3,150 & 4,165 \\
\hline Basic demographics & X & X & X & X & X & $\mathrm{X}$ & $\mathrm{X}$ & X & X \\
\hline Income FE & $\mathrm{X}$ & $\mathrm{X}$ & $X$ & $X$ & $\mathrm{X}$ & $X$ & $\mathrm{X}$ & $\mathrm{X}$ & $\mathrm{X}$ \\
\hline Year FE & $\mathrm{X}$ & $X$ & $X$ & $X$ & $X$ & $X$ & $X$ & $\mathrm{X}$ & $\mathrm{X}$ \\
\hline Age FE & $\mathrm{X}$ & $\mathrm{X}$ & $X$ & $X$ & $X$ & $X$ & $X$ & $X$ & $X$ \\
\hline Pref. survey FE & $\mathrm{X}$ & $\mathrm{X}$ & $X$ & $X$ & $X$ & $X$ & $\mathrm{X}$ & $\mathrm{X}$ & $\mathrm{X}$ \\
\hline Pref. at $15 \mathrm{FE}$ & $\mathrm{X}$ & $X$ & $X$ & $X$ & $X$ & $X$ & $X$ & $X$ & $\mathrm{X}$ \\
\hline (Pref. at $15 \mathrm{FE})^{*}$ age & $\mathrm{X}$ & $\mathrm{X}$ & $\mathrm{X}$ & $\mathrm{X}$ & $\mathrm{X}$ & $\mathrm{X}$ & $X$ & $\mathrm{X}$ & $\mathrm{X}$ \\
\hline
\end{tabular}

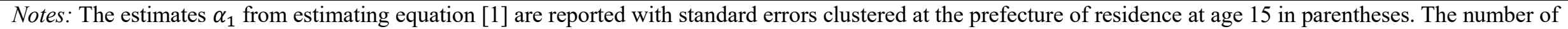

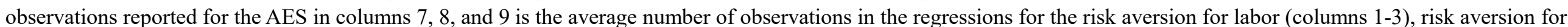
finance (columns 4-6), or all of them respectively. Significance levels: ${ }^{* * *} \mathrm{p}<0.01,{ }^{* *} \mathrm{p}<0.05,{ }^{*} \mathrm{p}<0.10$ 
Table 2

Robustness checks

\begin{tabular}{|c|c|c|c|c|c|c|c|}
\hline & $(1)$ & (2) & (3) & (4) & $(5)$ & $(6)$ & (7) \\
\hline & Baseline & $\begin{array}{l}\text { +Cohort } \\
\text { dummies }\end{array}$ & $\begin{array}{c}+ \text { Year by } \\
\text { Pref survey } \\
\text { FE }\end{array}$ & $\begin{array}{l}\text { Restricting to } \\
\text { non-movers }\end{array}$ & $\begin{array}{c}\text { Add } \\
\text { GNP per capita }\end{array}$ & $\begin{array}{c}\text { Add } \\
\text { WWII variables }\end{array}$ & $\begin{array}{l}\text { Using } \\
5 \% \text { threshold }\end{array}$ \\
\hline Economic shock & $\begin{array}{l}0.151 * * * \\
(0.037)\end{array}$ & $\begin{array}{c}0.172 * * * \\
(0.047)\end{array}$ & $\begin{array}{c}0.174 * * * \\
(0.048)\end{array}$ & $\begin{array}{c}0.137 * * * \\
(0.051)\end{array}$ & $\begin{array}{c}0.147 * * * \\
(0.039)\end{array}$ & $\begin{array}{c}0.180 * * * \\
(0.052)\end{array}$ & $\begin{array}{c}0.181 * * * \\
(0.040)\end{array}$ \\
\hline $\mathrm{N}$ & 4,165 & 4,165 & 4,105 & 2,746 & 4,141 & 4,090 & 4,165 \\
\hline Basic demographics & X & X & $\mathrm{X}$ & $\mathrm{X}$ & X & X & X \\
\hline Income FE & $X$ & $X$ & $\mathrm{X}$ & $X$ & $\mathrm{X}$ & $X$ & $\mathrm{X}$ \\
\hline Year FE & $\mathrm{X}$ & $\mathrm{X}$ & $\mathrm{X}$ & $\mathrm{X}$ & $\mathrm{X}$ & $\mathrm{X}$ & $\mathrm{X}$ \\
\hline Age FE & $\mathrm{X}$ & $\mathrm{X}$ & $\mathrm{X}$ & $\mathrm{X}$ & $\mathrm{X}$ & $\mathrm{X}$ & $\mathrm{X}$ \\
\hline Pref. survey FE & $X$ & $\mathrm{X}$ & $X$ & $\mathrm{X}$ & $X$ & $X$ & $\mathrm{X}$ \\
\hline Pref. at $15 \mathrm{FE}$ & $X$ & $\mathrm{X}$ & $\mathrm{X}$ & $\mathrm{X}$ & $\mathrm{X}$ & $\mathrm{X}$ & $\mathrm{X}$ \\
\hline (Pref. at $15 \mathrm{FE})^{*}$ age & $\mathrm{X}$ & $\mathrm{X}$ & $X$ & $\mathrm{X}$ & $\mathrm{X}$ & $X$ & $X$ \\
\hline Cohort FE & & $X$ & $X$ & & & & \\
\hline Year by Pref survey FE & & & $\mathrm{X}$ & & & & \\
\hline Educ father at 15 & & & $X$ & & & & \\
\hline Educ mother at 15 & & & $X$ & & & & \\
\hline GNP per capita & & & & & $X$ & & \\
\hline WWII variables & & & & & & $\mathrm{X}$ & \\
\hline $\begin{array}{l}\text { Notes: AES for all six risk av } \\
\text { further add year-by-prefecture } \\
\text { to the prefecture at age } 15 \text {. C } \\
\text { fixed effects with the numbe } \\
\text { Economic shock to the } 5^{\text {th }} \text { pe } \\
p<0.01,{ }^{* * *} p<0.05,{ }^{*} p<0.10\end{array}$ & $\begin{array}{l}\text { measures ar } \\
\text { vey FE, and } \\
\text { (5) controls } \\
\text { eaths and } m \\
\text { e instead of }\end{array}$ & $\begin{array}{l}\text { ed. Column } \\
\text { on of fathers } \\
\text { ecture-level } \\
\text { er capita, an } \\
\text { centile. The }\end{array}$ & $\begin{array}{l}\text { varying GNP } \\
\text { mber of buildi } \\
\text { esults for each }\end{array}$ & $\begin{array}{l}\text { Co results from c } \\
\text { Column (4) rest } \\
\text { capita during im! } \\
\text { collapsed per ca } \\
\text { umn of this tabl }\end{array}$ & $\begin{array}{l}\mathrm{mn}(9) \text { of Table } 1 . \\
\text { s the sample to non } \\
\text { sionable years. Co } \\
\text { due to WWII. Cc } \\
\text { e presented in App }\end{array}$ & $\begin{array}{l}\text { lumn (2) add cohort } \\
\text { overs whose curren } \\
\text { nn (6) includes an ir } \\
\text { mn (7) uses the thr } \\
\text { dix Tables A3-A9. }\end{array}$ & $\begin{array}{l}\text { mmies. Column } \\
\text { efecture is ident } \\
\text { action of the co } \\
\text { old of defining } \\
\text { nificance levels }\end{array}$ \\
\hline
\end{tabular}


Table 3

Other age ranges

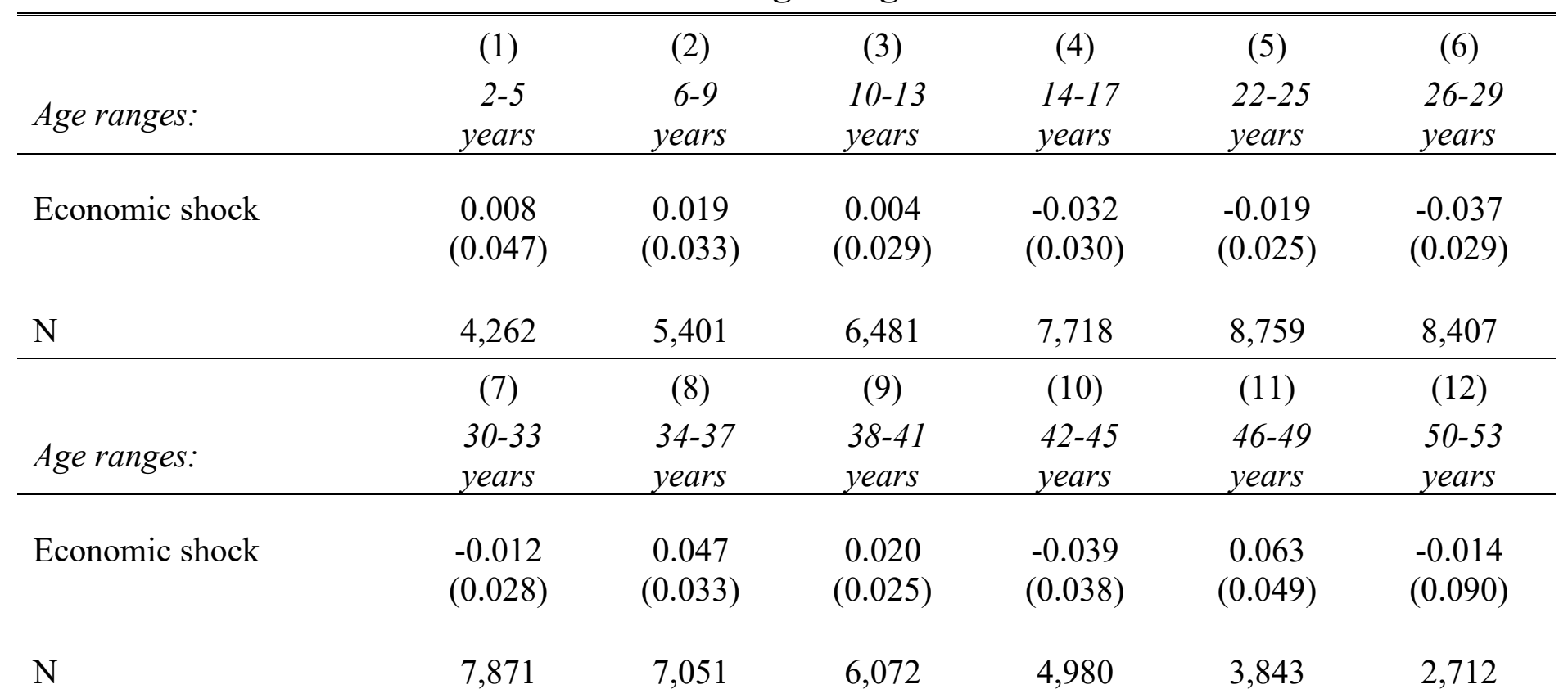

Notes: AES for all six risk aversion measures are reported. We repeat our baseline specification [1] based on different four-year range intervals (2-5, 6-9, ... and 50-53). The full estimates for each risk aversion outcome are reported in Appendix Table A13. Significance levels: ${ }^{* * *} \mathrm{p}<0.01,{ }^{* *} \mathrm{p}<0.05,{ }^{*} \mathrm{p}<0.10$ 
Table 4

\section{Heterogeneity}

\begin{tabular}{|c|c|c|c|c|c|c|c|c|c|c|}
\hline & \multicolumn{2}{|c|}{ Own education } & \multicolumn{2}{|c|}{ Mother's education } & \multicolumn{2}{|c|}{ Income } & \multicolumn{4}{|c|}{ Age } \\
\hline & $\begin{array}{l}\text { Less than } \\
\text { high school }\end{array}$ & $\begin{array}{l}\text { More than } \\
\text { high school }\end{array}$ & $\begin{array}{l}\text { Less than } \\
\text { junior high } \\
\text { school }\end{array}$ & $\begin{array}{c}\text { More than } \\
\text { junior high } \\
\text { school }\end{array}$ & $\begin{array}{l}\text { Below } \\
\text { median }\end{array}$ & $\begin{array}{l}\text { Above } \\
\text { median }\end{array}$ & $\begin{array}{l}22-29 \\
\text { years }\end{array}$ & $\begin{array}{l}30-39 \\
\text { years }\end{array}$ & $\begin{array}{l}40-49 \\
\text { years }\end{array}$ & $\begin{array}{l}50-59 \\
\text { years }\end{array}$ \\
\hline & $(1)$ & $(2)$ & (3) & $(4)$ & $(5)$ & $(6)$ & (7) & $(8)$ & (9) & $(10)$ \\
\hline Economic shock & $\begin{array}{c}0.152 * * * \\
(0.057)\end{array}$ & $\begin{array}{c}0.174 * * * \\
(0.045)\end{array}$ & $\begin{array}{c}0.182 * * * \\
(0.063)\end{array}$ & $\begin{array}{c}0.099 * * \\
(0.050)\end{array}$ & $\begin{array}{c}0.190 * * * \\
(0.045)\end{array}$ & $\begin{array}{l}0.118 * \\
(0.064)\end{array}$ & $\begin{array}{c}0.357 \\
(0.328)\end{array}$ & $\begin{array}{c}0.260 * * * \\
(0.090)\end{array}$ & $\begin{array}{c}0.382 * * * \\
(0.105)\end{array}$ & $\begin{array}{c}0.081 \\
(0.070)\end{array}$ \\
\hline $\mathrm{N}$ & 2,174 & 1,988 & 1,890 & 2,258 & 2,686 & 1,477 & 269 & 779 & 1,218 & 1,469 \\
\hline
\end{tabular}


Table 5

Labor market outcomes

\begin{tabular}{lcccccccc}
\hline \hline & & & & & & & & \\
& Employed & Hours & Income & Firm size & Industry & $\begin{array}{c}\text { Self- } \\
\text { employed }\end{array}$ & $\begin{array}{c}\text { Tenure } \\
\text { (excl. self- } \\
\text { employed) }\end{array}$ \\
& $(1)$ & $(2)$ & $(3)$ & $(4)$ & $(5)$ & $(6)$ & $(7)$ & $(8)$ \\
\hline Economic shock & 0.012 & 0.148 & $33.241^{*}$ & 76.100 & 0.215 & $-0.036^{* * *}$ & 0.766 & $1.079^{*}$ \\
& $(0.009)$ & $(0.830)$ & $(17.570)$ & $(78.573)$ & $(0.171)$ & $(0.013)$ & $(0.532)$ & $(0.573)$ \\
\hline R-squared & 0.94 & 0.85 & 0.81 & 0.36 & 0.83 & 0.20 & 0.80 & 0.81 \\
N & 9,716 & 9,272 & 8,867 & 8,028 & 8,764 & 10,021 & 8,737 & 7,290 \\
Mean & 0.927 & 43.712 & 712.657 & 945.834 & 6.846 & 0.126 & 17.632 & 17.317 \\
\hline
\end{tabular}

Notes: The estimates $\alpha_{1}$ from estimating equation [1] are reported with standard errors clustered at the prefecture of residence at age 15 in parentheses. Significance levels: ${ }^{* * *}$ $\mathrm{p}<0.01,{ }^{* *} \mathrm{p}<0.05,{ }^{*} \mathrm{p}<0.10$ 
Online Appendix (Not for Publication) 


\section{Appendix A: Additional Figures and Tables}

Figure A1

Fraction staying in the same prefecture as age 15

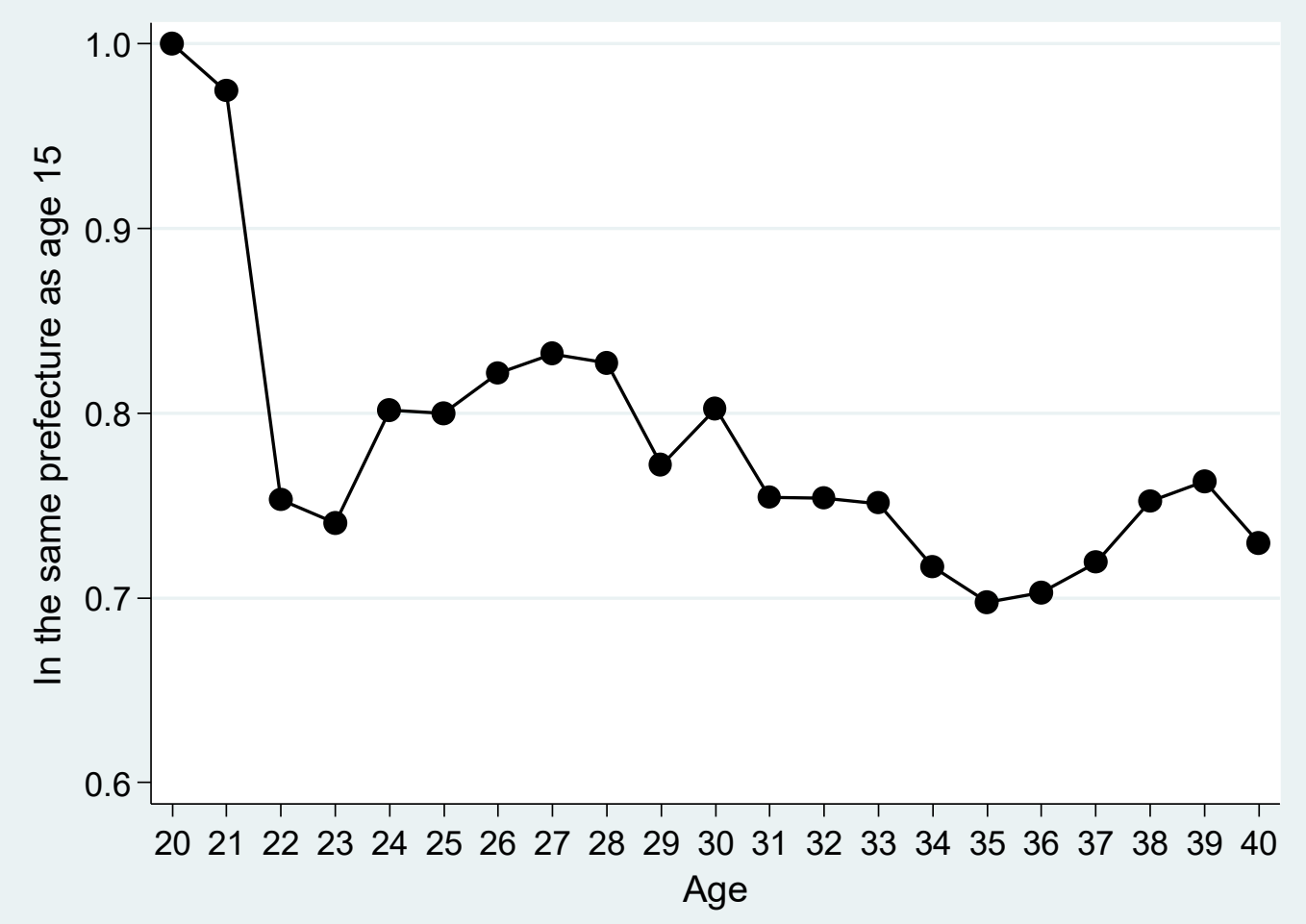

Notes: The fraction of individuals who live in the same prefecture as the age of 15 years is plotted by the current age. 


\section{Figure A2}

\section{Economic shocks by prefecture}

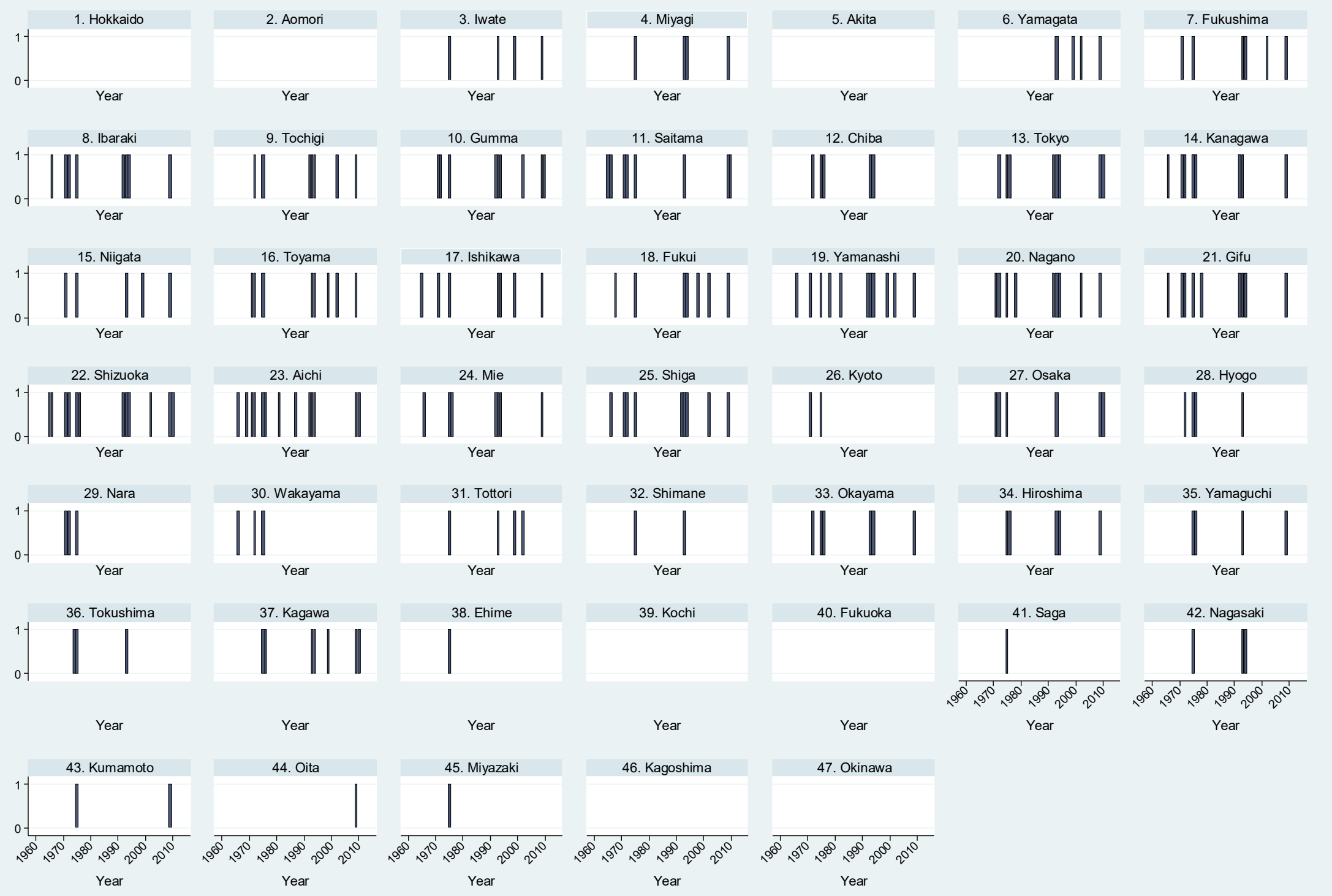

Notes: The figure shows how often each prefecture experienced economic shocks from 1963-2010. There is a total of 47 prefectures. 


\section{Figure A3}

\section{Frequency distributions of each risk preference measure}

A. Labor domain
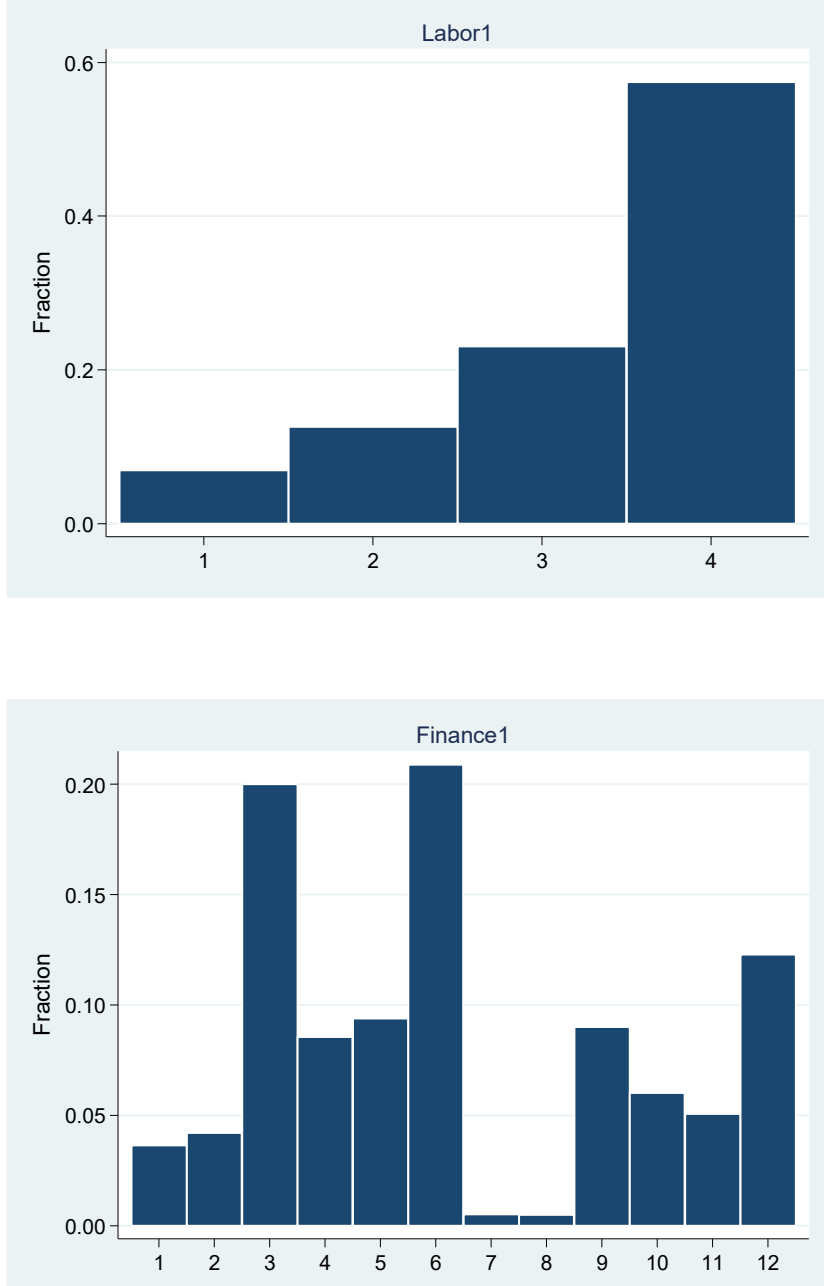

Labor2

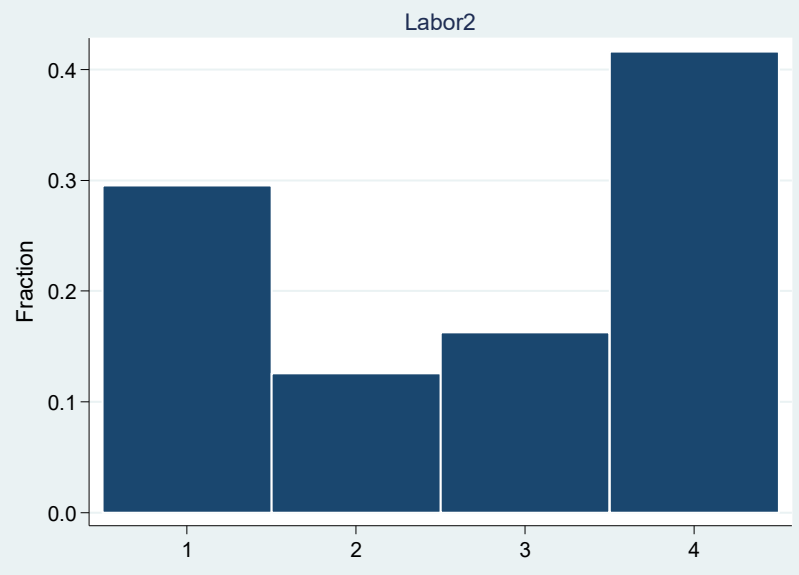

B. Finance domain

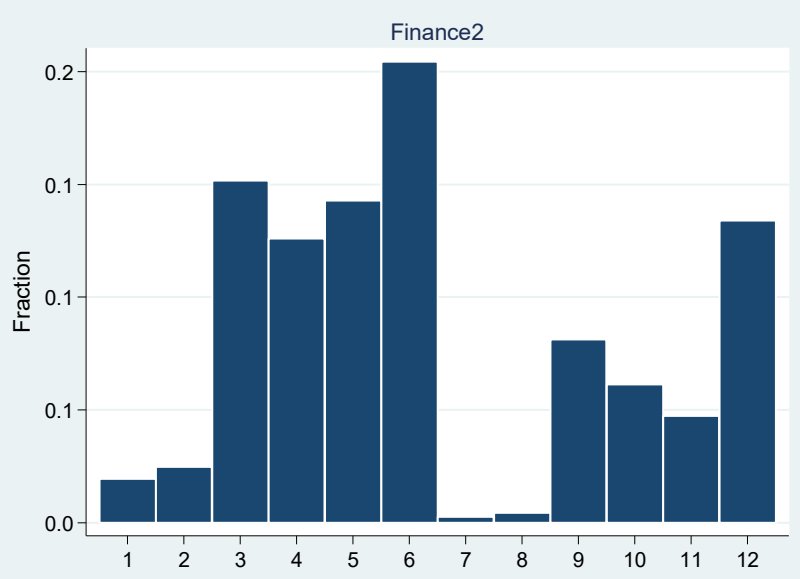

Labor3
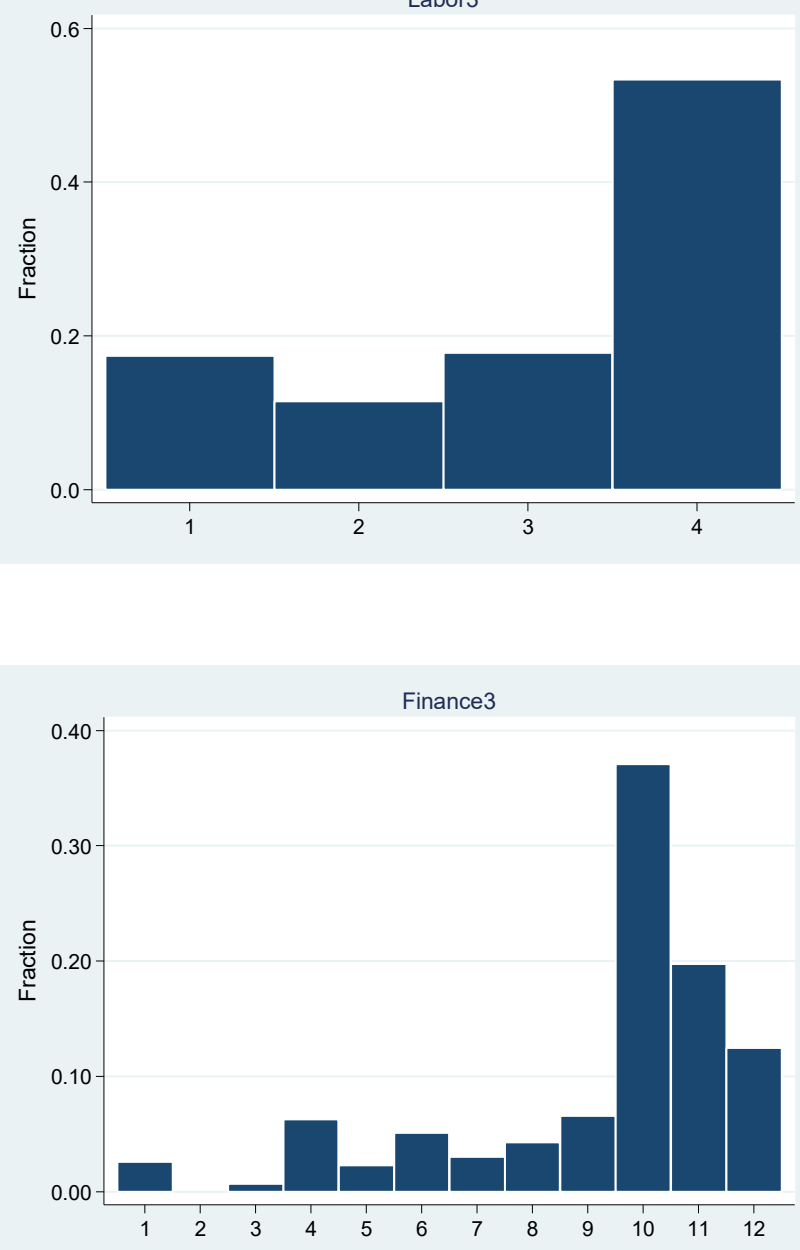

Notes: The figure displays the distribution of choice frequencies. The higher the number, the more risk averse the choice is. The exact formats of each question are displayed in Appendix Section B. 
Table A1

Summary statistics

\begin{tabular}{lccccc}
\hline \hline Variable & $\mathrm{N}$ & Mean & SD & Min & Max \\
\hline Birth year & 10,065 & 1961.43 & 10.67 & 1946 & 1989 \\
Age & 10,065 & 47.17 & 10.68 & 22 & 65 \\
Married & 10,040 & 0.78 & 0.42 & 0 & 1 \\
Low educated & 10,053 & 0.53 & 0.50 & 0 & 1 \\
Risk preference (Labor 1) & 8,928 & 0.57 & 0.49 & 0 & 1 \\
Risk preference (Labor 2) & 7,242 & 0.42 & 0.49 & 0 & 1 \\
Risk preference (Labor 3) & 1,719 & 0.53 & 0.50 & 0 & 1 \\
Risk preference (Finance 1) & 3,770 & 0.12 & 0.33 & 0 & 1 \\
Risk preference (Finance 2) & 3,768 & 0.13 & 0.34 & 0 & 1 \\
Risk preference (Finance 3) & 3,734 & 0.12 & 0.33 & 0 & 1 \\
Possess financial asset & 9,336 & 0.27 & 0.44 & 0 & 1 \\
Don't wear seatbelt & 10,065 & 0.10 & 0.30 & 0 & 1 \\
Employed & 9,746 & 0.93 & 0.26 & 0 & 1 \\
Hours of work & 9,312 & 43.71 & 20.22 & 0 & 160 \\
Income & 8,892 & 712.66 & 402.78 & 50 & 2000 \\
Tenure & 8,762 & 17.63 & 11.68 & 1 & 40 \\
Firm size & 8,051 & 945.83 & 1640.87 & 3 & 5000 \\
Industry & 8,790 & 6.85 & 3.32 & 1 & 12 \\
Self-employed & 10,065 & 0.13 & 0.33 & 0 & 1 \\
\hline
\end{tabular}

Notes: See text for the construction of each risk preference measure. Appendix Section B shows the exact formats of risk preference questions. All risk preference measures are values before standardization. 
Table A2

Correlation among risk preference measures

\begin{tabular}{|c|c|c|c|c|c|c|}
\hline & Labor1 & Labor2 & Labor3 & Financel & Finance2 & Finance 3 \\
\hline Labor1 & & $0.6701 * * *$ & $0.7595 * * *$ & $0.1489 * * *$ & $0.1652 * * *$ & $0.1222 * * *$ \\
\hline Labor2 & & & - & $0.2022 * * *$ & $0.2122 * * *$ & $0.1600 * * *$ \\
\hline Labor3 & & & & $0.1543 * * *$ & $0.1616^{* * *}$ & $0.0981 * * *$ \\
\hline Finance1 & & & & & $0.6956^{* * *}$ & $0.2824 * * *$ \\
\hline Finance2 & & & & & & $0.3078 * * *$ \\
\hline Finance 3 & & & & & & \\
\hline
\end{tabular}

Notes: The table displays the pair-wise correlation between our risk aversion measures. There is no overlap between labor2 and labor3.

\section{Table A3}

\begin{tabular}{c|ccc} 
& \multicolumn{3}{|c}{ Verification of risk measures } \\
& Gamble often & $\begin{array}{c}\text { Possess } \\
\text { financial asset }\end{array}$ & $\begin{array}{c}\text { Rarely wear } \\
\text { seatbelt }\end{array}$ \\
\hline Labor1 & $-0.0486^{* * *}$ & $-0.0672 * * *$ & $-0.0573 * * *$ \\
Labor2 & $-0.0429 * * *$ & $-0.0732 * * *$ & $-0.0638^{* * *}$ \\
Labor3 & $-0.0891 * * *$ & $-0.0410^{*}$ & - \\
Finance1 & $-0.0575^{* * *}$ & -0.0212 & - \\
Finance2 & $-0.0291^{*}$ & -0.0130 & - \\
Finance3 & 0.0104 & -0.0214 & -
\end{tabular}

Notes: A gambling dummy takes one if the person is engaged in gambling twice a week. A possessing a financial asset dummy takes one if an individual owns stocks and corporate bonds in her/his portfolio. A rarely wearing seatbelts dummy takes one if an individual doesn't wear or rarely wear a seatbelt. There is no overlap in years between seatbelt dummy and four risk aversion measures. 
Table A4

Specification with cohort dummies

\begin{tabular}{|c|c|c|c|c|c|c|c|c|c|}
\hline & $(1)$ & $(2)$ & (3) & (4) & $(5)$ & $(6)$ & $(7)$ & $(8)$ & $(9)$ \\
\hline & Labor 1 & Labor2 & Labor3 & Finance1 & Finance2 & Finance3 & $\begin{array}{c}\text { AES } \\
\text { Labor }\end{array}$ & $\begin{array}{c}\text { AES } \\
\text { Finance }\end{array}$ & $\begin{array}{c}\text { AES } \\
\text { All }\end{array}$ \\
\hline Economic shock & $\begin{array}{c}0.128 * * \\
(0.054)\end{array}$ & $\begin{array}{c}0.126^{* *} \\
(0.059)\end{array}$ & $\begin{array}{c}0.331 * * * \\
(0.118)\end{array}$ & $\begin{array}{c}0.150 * \\
(0.079)\end{array}$ & $\begin{array}{c}0.100 \\
(0.089)\end{array}$ & $\begin{array}{c}0.180 * * \\
(0.073)\end{array}$ & $\begin{array}{c}0.195 * * * \\
(0.057)\end{array}$ & $\begin{array}{c}0.150 * * \\
(0.061)\end{array}$ & $\begin{array}{c}0.172 * * * \\
(0.047)\end{array}$ \\
\hline $\begin{array}{l}\text { R-squared } \\
\mathrm{N}\end{array}$ & $\begin{array}{c}0.10 \\
7,749 \\
\end{array}$ & $\begin{array}{c}0.11 \\
6,361 \\
\end{array}$ & $\begin{array}{c}0.19 \\
1,428 \\
\end{array}$ & $\begin{array}{c}0.11 \\
3,156 \\
\end{array}$ & $\begin{array}{c}0.12 \\
3,159 \\
\end{array}$ & $\begin{array}{c}0.11 \\
3,134 \\
\end{array}$ & 5,179 & 3,150 & 4,165 \\
\hline
\end{tabular}

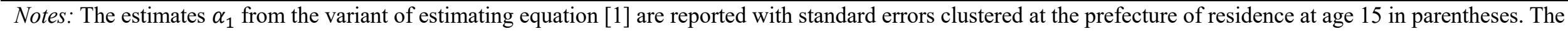

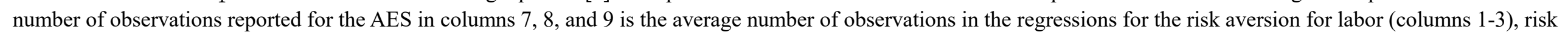
aversion for finance (columns 4-6), or all of them respectively. Significance levels: ${ }^{* * *} \mathrm{p}<0.01,{ }^{* *} \mathrm{p}<0.05,{ }^{*} \mathrm{p}<0.10$

\section{Table A5}

Specification with cohort effects, prefecture-year interactions, and additional controls

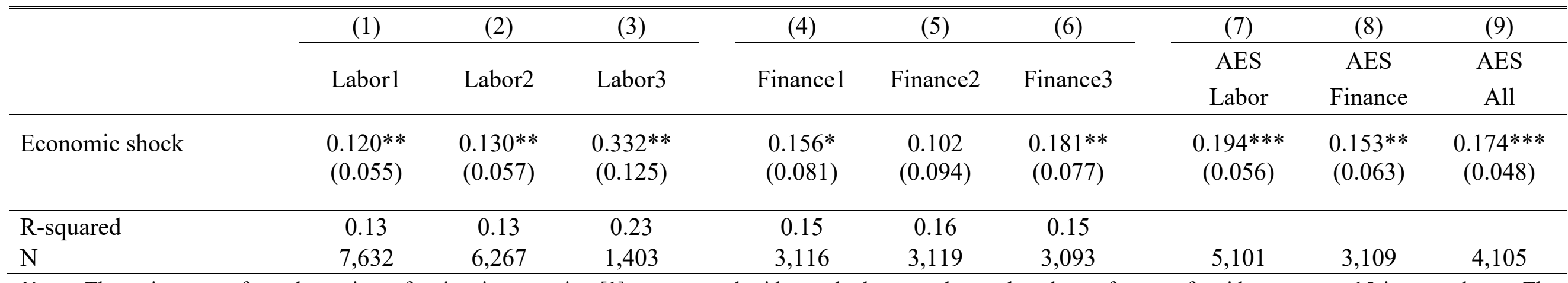

Notes: The estimates $\alpha_{1}$ from the variant of estimating equation [1] are reported with standard errors clustered at the prefecture of residence at age 15 in parentheses. The number of observations reported for the AES in columns 7, 8, and 9 is the average number of observations in the regressions for the risk aversion for labor (columns 1-3), risk aversion for finance (columns 4-6), or all of them respectively. Significance levels: ${ }^{* * *} \mathrm{p}<0.01,{ }^{* *} \mathrm{p}<0.05,{ }^{*} \mathrm{p}<0.10$ 
Table A6

Restricting sample to non-movers

\begin{tabular}{|c|c|c|c|c|c|c|c|c|c|}
\hline & (1) & (2) & (3) & (4) & $(5)$ & (6) & (7) & (8) & (9) \\
\hline & Labor 1 & Labor2 & Labor3 & Finance1 & Finance2 & Finance3 & $\begin{array}{c}\text { AES } \\
\text { Labor }\end{array}$ & $\begin{array}{c}\text { AES } \\
\text { Finance }\end{array}$ & $\begin{array}{c}\text { AES } \\
\text { All }\end{array}$ \\
\hline Economic shock & $\begin{array}{c}0.121 * * * \\
(0.040)\end{array}$ & $\begin{array}{c}0.135 * * \\
(0.056)\end{array}$ & $\begin{array}{c}0.284 * * \\
(0.138)\end{array}$ & $\begin{array}{c}0.089 \\
(0.080)\end{array}$ & $\begin{array}{c}0.037 \\
(0.097)\end{array}$ & $\begin{array}{c}0.145^{*} \\
(0.076)\end{array}$ & $\begin{array}{c}0.180 * * * \\
(0.057)\end{array}$ & $\begin{array}{c}0.095 \\
(0.068)\end{array}$ & $\begin{array}{c}0.137 * * * \\
(0.051)\end{array}$ \\
\hline $\begin{array}{l}\text { R-squared } \\
\mathrm{N}\end{array}$ & $\begin{array}{c}0.09 \\
5,505\end{array}$ & $\begin{array}{c}0.10 \\
4,456\end{array}$ & $\begin{array}{c}0.17 \\
1,089\end{array}$ & $\begin{array}{c}0.12 \\
1,814\end{array}$ & $\begin{array}{c}0.12 \\
1,810\end{array}$ & $\begin{array}{c}0.12 \\
1,802\end{array}$ & 3,683 & 1,809 & 2,746 \\
\hline
\end{tabular}

Notes: The estimates $\alpha_{1}$ from estimating equation [1] are reported with standard errors clustered at the prefecture of residence at age 15 in parentheses. The number of observations reported for the AES in columns 7, 8, and 9 is the average number of observations in the regressions for the risk aversion for labor (columns 1-3), risk aversion for finance (columns 4-6), or all of them respectively. Significance levels: ${ }^{* * *} \mathrm{p}<0.01,{ }^{* *} \mathrm{p}<0.05,{ }^{*} \mathrm{p}<0.10$

\section{Table A7}

Adding prefecture-level GNP per capita

\begin{tabular}{|c|c|c|c|c|c|c|c|c|c|}
\hline & $(1)$ & $(2)$ & (3) & (4) & $(5)$ & (6) & $(7)$ & $(8)$ & (9) \\
\hline & Labor1 & Labor2 & Labor3 & Finance1 & Finance2 & Finance3 & $\begin{array}{c}\text { AES } \\
\text { Labor }\end{array}$ & $\begin{array}{c}\text { AES } \\
\text { Finance }\end{array}$ & $\begin{array}{c}\text { AES } \\
\text { All }\end{array}$ \\
\hline Economic shock & $\begin{array}{c}0.120 * * * \\
(0.034)\end{array}$ & $\begin{array}{c}0.121 * * * \\
(0.045)\end{array}$ & $\begin{array}{c}0.302 * * * \\
(0.108)\end{array}$ & $\begin{array}{c}0.130^{*} \\
(0.066)\end{array}$ & $\begin{array}{c}0.036 \\
(0.072)\end{array}$ & $\begin{array}{c}0.157 * * \\
(0.071)\end{array}$ & $\begin{array}{c}0.181 * * * \\
(0.047)\end{array}$ & $\begin{array}{c}0.113 * * \\
(0.054)\end{array}$ & $\begin{array}{c}0.147 * * * \\
(0.039)\end{array}$ \\
\hline $\begin{array}{l}\text { R-squared } \\
\mathrm{N}\end{array}$ & $\begin{array}{c}0.09 \\
7,749\end{array}$ & $\begin{array}{c}0.10 \\
6,361 \\
\end{array}$ & $\begin{array}{c}0.16 \\
1,428 \\
\end{array}$ & $\begin{array}{c}0.09 \\
3,156 \\
\end{array}$ & $\begin{array}{c}0.11 \\
3,159 \\
\end{array}$ & $\begin{array}{l}0.09 \\
3134\end{array}$ & 5,179 & 3,158 & 4,371 \\
\hline
\end{tabular}

Notes: The estimates $\alpha_{1}$ from estimating equation [1] are reported with standard errors clustered at the prefecture of residence at age 15 in parentheses. The number of observations reported for the AES in columns 7, 8, and 9 is the average number of observations in the regressions for the risk aversion for labor (columns 1-3), risk aversion for finance (columns 4-6), or all of them respectively. Significance levels: ${ }^{* * *} p<0.01,{ }^{* *} p<0.05,{ }^{*} p<0.10$ 
Table A8

Adding WWII variables-cohort interactions

\begin{tabular}{|c|c|c|c|c|c|c|c|c|c|}
\hline & (1) & $(2)$ & (3) & (4) & $(5)$ & $(6)$ & (7) & (8) & (9) \\
\hline & Labor1 & Labor2 & Labor3 & Finance1 & Finance2 & Finance3 & $\begin{array}{l}\text { AES } \\
\text { Labor }\end{array}$ & $\begin{array}{c}\text { AES } \\
\text { Finance }\end{array}$ & $\begin{array}{c}\text { AES } \\
\text { All }\end{array}$ \\
\hline Economic shock & $\begin{array}{c}0.126^{* *} \\
(0.054)\end{array}$ & $\begin{array}{c}0.129 * * \\
(0.064)\end{array}$ & $\begin{array}{c}0.345 * * \\
(0.133)\end{array}$ & $\begin{array}{c}0.141 \\
(0.088)\end{array}$ & $\begin{array}{c}0.102 \\
(0.091)\end{array}$ & $\begin{array}{c}0.214 * * * \\
(0.077)\end{array}$ & $\begin{array}{c}0.200 * * * \\
(0.058)\end{array}$ & $\begin{array}{c}0.159 * * \\
(0.064)\end{array}$ & $\begin{array}{c}0.180 * * * \\
(0.052)\end{array}$ \\
\hline $\begin{array}{l}\text { R-squared } \\
\mathrm{N}\end{array}$ & $\begin{array}{c}0.12 \\
7,597\end{array}$ & $\begin{array}{c}0.13 \\
6,235\end{array}$ & $\begin{array}{c}0.25 \\
1,402\end{array}$ & $\begin{array}{c}0.15 \\
3,107\end{array}$ & $\begin{array}{c}0.16 \\
3,111\end{array}$ & $\begin{array}{c}0.14 \\
3,085\end{array}$ & 5,078 & 3,101 & 4,090 \\
\hline
\end{tabular}

Notes: The estimates $\alpha_{1}$ from estimating equation [1] are reported with standard errors clustered at the prefecture of residence at age 15 in parentheses. The number of observations reported for the AES in columns 7, 8, and 9 is the average number of observations in the regressions for the risk aversion for labor (columns 1-3), risk aversion for finance (columns 4-6), or all of them respectively. Significance levels: ${ }^{* * *} \mathrm{p}<0.01,{ }^{* *} \mathrm{p}<0.05,{ }^{*} \mathrm{p}<0.10$

\section{Table A9}

\section{Using five percent as a threshold for Economic shock}

\begin{tabular}{|c|c|c|c|c|c|c|c|c|c|}
\hline & $(1)$ & (2) & (3) & (4) & $(5)$ & $(6)$ & (7) & $(8)$ & $(9)$ \\
\hline & Labor1 & Labor2 & Labor3 & Finance1 & Finance2 & Finance3 & $\begin{array}{c}\text { AES } \\
\text { Labor }\end{array}$ & $\begin{array}{c}\text { AES } \\
\text { Finance }\end{array}$ & $\begin{array}{c}\text { AES } \\
\text { All }\end{array}$ \\
\hline Economic shock & $\begin{array}{c}0.089 * * \\
(0.043)\end{array}$ & $\begin{array}{c}0.103 * * \\
(0.049)\end{array}$ & $\begin{array}{c}0.323 * * \\
(0.130)\end{array}$ & $\begin{array}{c}0.257 * * * \\
(0.073)\end{array}$ & $\begin{array}{l}0.147 * \\
(0.073)\end{array}$ & $\begin{array}{c}0.141 \\
(0.089)\end{array}$ & $\begin{array}{c}0.171 * * * \\
(0.050)\end{array}$ & $\begin{array}{c}0.19 * * * \\
(0.062)\end{array}$ & $\begin{array}{c}0.181 * * * \\
(0.040)\end{array}$ \\
\hline $\begin{array}{l}\text { R-squared } \\
\mathrm{N}\end{array}$ & $\begin{array}{c}0.09 \\
7,749\end{array}$ & $\begin{array}{c}0.10 \\
6,361\end{array}$ & $\begin{array}{c}0.16 \\
1,428\end{array}$ & $\begin{array}{c}0.10 \\
3,156\end{array}$ & $\begin{array}{c}0.11 \\
3,159\end{array}$ & $\begin{array}{c}0.09 \\
3,134\end{array}$ & 5,179 & 3,150 & 4,165 \\
\hline
\end{tabular}

Notes: The estimates $\alpha_{1}$ from estimating equation [1] are reported with standard errors clustered at the prefecture of residence at age 15 in parentheses. The number of observations reported for the AES in columns 7, 8, and 9 is the average number of observations in the regressions for the risk aversion for labor (columns 1-3), risk aversion for finance (columns 4-6), or all of them respectively. Significance levels: ${ }^{* * *} \mathrm{p}<0.01,{ }^{* *} \mathrm{p}<0.05,{ }^{*} \mathrm{p}<0.10$ 
Table A10

Without standardizing each outcome

\begin{tabular}{|c|c|c|c|c|c|c|c|c|c|}
\hline & (1) & $(2)$ & $(3)$ & (4) & $(5)$ & $(6)$ & $(7)$ & $(8)$ & $(9)$ \\
\hline & Labor1 & Labor2 & Labor3 & Finance1 & Finance2 & Finance3 & $\begin{array}{c}\text { AES } \\
\text { Labor }\end{array}$ & $\begin{array}{c}\text { AES } \\
\text { Finance }\end{array}$ & $\begin{array}{c}\text { AES } \\
\text { All }\end{array}$ \\
\hline Economic shock & $\begin{array}{c}0.058 * * * \\
(0.017)\end{array}$ & $\begin{array}{c}0.060 * * \\
(0.022)\end{array}$ & $\begin{array}{c}0.148 * * * \\
(0.051)\end{array}$ & $\begin{array}{c}0.047 * * \\
(0.022)\end{array}$ & $\begin{array}{c}0.019 \\
(0.024)\end{array}$ & $\begin{array}{c}0.051 * * \\
(0.023)\end{array}$ & $\begin{array}{c}0.178^{* * *} \\
(0.045)\end{array}$ & $\begin{array}{c}0.124 * * \\
(0.053)\end{array}$ & $\begin{array}{c}0.151 * * * \\
(0.037)\end{array}$ \\
\hline $\begin{array}{l}\text { R-squared } \\
\mathrm{N}\end{array}$ & $\begin{array}{c}0.61 \\
7,749\end{array}$ & $\begin{array}{c}0.47 \\
6,361\end{array}$ & $\begin{array}{c}0.60 \\
1,428\end{array}$ & $\begin{array}{c}0.20 \\
3,156\end{array}$ & $\begin{array}{c}0.23 \\
3,159\end{array}$ & $\begin{array}{c}0.20 \\
3,134\end{array}$ & 5,179 & 3,150 & 4,165 \\
\hline
\end{tabular}

Notes: The estimates $\alpha_{1}$ from estimating equation [1] are reported with standard errors clustered at the prefecture of residence at age 15 in parentheses. The number of observations reported for the AES in columns 7, 8, and 9 is the average number of observations in the regressions for the risk aversion for labor (columns 1-3), risk aversion for finance (columns 4-6), or all of them respectively. Significance levels: ${ }^{* * *} \mathrm{p}<0.01,{ }^{* *} \mathrm{p}<0.05,{ }^{*} \mathrm{p}<0.10$

\section{Table A11}

\section{Risk aversion parameters as outcomes}

\begin{tabular}{|c|c|c|c|c|c|c|c|c|}
\hline & (1) & (2) & (3) & (4) & $(5)$ & (6) & (7) & (8) \\
\hline & Labor1 & Labor2 & Finance1 & Finance2 & Finance3 & $\begin{array}{l}\text { AES } \\
\text { Labor }\end{array}$ & $\begin{array}{c}\text { AES } \\
\text { Finance }\end{array}$ & $\begin{array}{c}\text { AES } \\
\text { All }\end{array}$ \\
\hline Economic shock & $\begin{array}{c}0.524 * * * \\
(0.145)\end{array}$ & $\begin{array}{c}0.505 * * * \\
(0.168)\end{array}$ & $\begin{array}{c}0.046 \\
(0.028)\end{array}$ & $\begin{array}{c}0.016 \\
(0.024)\end{array}$ & $\begin{array}{l}-0.030 \\
(0.021)\end{array}$ & $\begin{array}{c}0.129 * * * \\
(0.036)\end{array}$ & $\begin{array}{c}0.014 \\
(0.038)\end{array}$ & $\begin{array}{c}0.060 * * \\
(0.024)\end{array}$ \\
\hline R-squared & 0.75 & 0.79 & 0.62 & 0.73 & 0.88 & & & \\
\hline $\mathrm{N}$ & 7,749 & 6,361 & 3,156 & 3,159 & 3,134 & 7,055 & 3,150 & 4,712 \\
\hline
\end{tabular}

Notes: The estimates $\alpha_{1}$ from estimating equation [1] are reported with standard errors clustered at the prefecture of residence at age 15 in parentheses. The number of observations reported for the AES in columns 7, 8, and 9 is the average number of observations in the regressions for the risk aversion for labor (columns 1-2), risk aversion for finance (columns 3-5), or all of them respectively. Labor3 cannot be converted to a risk aversion parameter. Significance levels: ${ }^{* * *} \mathrm{p}<0.01,{ }^{* *} \mathrm{p}<0.05,{ }^{*} \mathrm{p}<0.10$ 
Table A12

Ordered logit specification

\begin{tabular}{lcccccccc}
\hline \hline & $(1)$ & $(2)$ & $(3)$ & & $(4)$ & $(5)$ & $(6)$ \\
\cline { 2 - 3 } \cline { 7 - 9 } & Labor1 & Labor2 & Labor3 & & Finance1 & Finance2 & Finance3 \\
\hline Economic shock & $\begin{array}{c}0.278^{* * *} \\
(0.067)\end{array}$ & $\begin{array}{c}0.293^{* * *} \\
(0.085)\end{array}$ & $\begin{array}{c}0.764^{* * *} \\
(0.198)\end{array}$ & & $\begin{array}{c}0.225^{* *} \\
(0.113)\end{array}$ & $\begin{array}{c}0.104 \\
(0.131)\end{array}$ & $\begin{array}{c}0.275^{* * *} \\
(0.103)\end{array}$ \\
\hline $\mathrm{N}$ & 7,749 & 6,361 & 1,428 & & 3,156 & 3,159 & 3,134 \\
\hline
\end{tabular}

Notes: The estimates from the ordered logit version of the equation [1] are reported with standard errors clustered at the prefecture of residence at age 15 in parentheses. 
Table A13

Other age ranges

\begin{tabular}{|c|c|c|c|c|c|c|c|c|c|}
\hline & $(1)$ & $(2)$ & $(3)$ & $(4)$ & $(5)$ & $(6)$ & $(7)$ & $(8)$ & $(9)$ \\
\hline & Labor1 & Labor2 & Labor3 & Financel & Finance2 & Finance 3 & $\begin{array}{c}\text { AES } \\
\text { Labor }\end{array}$ & $\begin{array}{c}\text { AES } \\
\text { Finance }\end{array}$ & $\begin{array}{c}\text { AES } \\
\text { All }\end{array}$ \\
\hline \multirow[b]{2}{*}{ Economic shock } & \multicolumn{9}{|c|}{ Age range: $2-5$ years } \\
\hline & $\begin{array}{l}-0.020 \\
(0.040)\end{array}$ & $\begin{array}{c}-0.011 \\
(0.054)\end{array}$ & $\begin{array}{l}-0.041 \\
(0.133)\end{array}$ & $\begin{array}{c}0.069 \\
(0.072)\end{array}$ & $\begin{array}{c}0.023 \\
(0.079)\end{array}$ & $\begin{array}{c}0.054 \\
(0.079)\end{array}$ & $\begin{array}{l}-0.032 \\
(0.051)\end{array}$ & $\begin{array}{c}0.048 \\
(0.064)\end{array}$ & $\begin{array}{c}0.008 \\
(0.047)\end{array}$ \\
\hline R-squared & 0.07 & 0.06 & 0.18 & 0.09 & 0.10 & 0.08 & & & \\
\hline Basic demographics & 8,240 & 6,829 & 1,413 & 3,025 & 3,039 & 3,026 & 5,494 & 3,030 & 4,262 \\
\hline & \multicolumn{9}{|c|}{ Age range: $6-9$ years } \\
\hline Economic shock & $\begin{array}{c}0.058 \\
(0.038)\end{array}$ & $\begin{array}{c}0.061 \\
(0.048)\end{array}$ & $\begin{array}{c}0.018 \\
(0.100)\end{array}$ & $\begin{array}{c}0.018 \\
(0.056)\end{array}$ & $\begin{array}{c}0.046 \\
(0.067)\end{array}$ & $\begin{array}{c}-0.076 \\
(0.083)\end{array}$ & $\begin{array}{c}0.042 \\
(0.048)\end{array}$ & $\begin{array}{c}-0.004 \\
(0.044)\end{array}$ & $\begin{array}{c}0.019 \\
(0.033)\end{array}$ \\
\hline R-squared & 0.07 & 0.06 & 0.14 & 0.07 & 0.08 & 0.07 & & & \\
\hline \multirow[t]{2}{*}{$\mathrm{N}$} & 10,326 & 8,545 & 1,793 & 3,910 & 3,924 & 3,908 & 6,888 & 3,914 & 5,401 \\
\hline & \multicolumn{9}{|c|}{ Age range: $10-13$ years } \\
\hline Economic shock & $\begin{array}{l}-0.022 \\
(0.031)\end{array}$ & $\begin{array}{c}-0.062 * \\
(0.035)\end{array}$ & $\begin{array}{c}0.055 \\
(0.086)\end{array}$ & $\begin{array}{l}-0.021 \\
(0.047)\end{array}$ & $\begin{array}{c}0.025 \\
(0.040)\end{array}$ & $\begin{array}{c}0.044 \\
(0.047)\end{array}$ & $\begin{array}{c}-0.008 \\
(0.036)\end{array}$ & $\begin{array}{c}0.016 \\
(0.035)\end{array}$ & $\begin{array}{c}0.004 \\
(0.029)\end{array}$ \\
\hline R-squared & 0.06 & 0.06 & 0.12 & 0.06 & 0.07 & 0.05 & & & \\
\hline \multirow[t]{2}{*}{$\mathrm{N}$} & 12,239 & 10,077 & 2,172 & 4,800 & 4,813 & 4,787 & 8,163 & 4,800 & 6,481 \\
\hline & \multicolumn{9}{|c|}{ Age range: $14-17$ years } \\
\hline Economic shock & $\begin{array}{c}-0.061 \\
(0.038)\end{array}$ & $\begin{array}{c}-0.014 \\
(0.040)\end{array}$ & $\begin{array}{l}-0.109 \\
(0.077)\end{array}$ & $\begin{array}{c}-0.028 \\
(0.054)\end{array}$ & $\begin{array}{l}-0.015 \\
(0.049)\end{array}$ & $\begin{array}{c}0.008 \\
(0.041)\end{array}$ & $\begin{array}{c}-0.054 \\
(0.043)\end{array}$ & $\begin{array}{l}-0.011 \\
(0.035)\end{array}$ & $\begin{array}{l}-0.032 \\
(0.030)\end{array}$ \\
\hline R-squared & 0.06 & 0.06 & 0.11 & 0.06 & 0.06 & 0.04 & & & \\
\hline \multirow[t]{2}{*}{$\mathrm{N}$} & 14,440 & 11,850 & 2,612 & 5,808 & 5,819 & 5,779 & 9,634 & 5,802 & 7,718 \\
\hline & \multicolumn{9}{|c|}{ Age range: $22-25$ years } \\
\hline Economic shock & $\begin{array}{c}0.018 \\
(0.031)\end{array}$ & $\begin{array}{c}0.000 \\
(0.031)\end{array}$ & $\begin{array}{c}-0.169 * * \\
(0.080)\end{array}$ & $\begin{array}{l}-0.008 \\
(0.049)\end{array}$ & $\begin{array}{c}0.037 \\
(0.042)\end{array}$ & $\begin{array}{c}0.005 \\
(0.028)\end{array}$ & $\begin{array}{c}-0.05 \\
(0.035)\end{array}$ & $\begin{array}{c}0.012 \\
(0.030)\end{array}$ & $\begin{array}{l}-0.019 \\
(0.025)\end{array}$ \\
\hline R-squared & 0.05 & 0.06 & 0.10 & 0.05 & 0.07 & 0.03 & & & \\
\hline $\mathrm{N}$ & 16,213 & 13,263 & 2,974 & 6,716 & 6,724 & 6,666 & 10,817 & 6,702 & 8,759 \\
\hline
\end{tabular}


Table A13 (continued)

Other age ranges

\begin{tabular}{|c|c|c|c|c|c|c|c|c|c|}
\hline & $(1)$ & $(2)$ & (3) & (4) & $(5)$ & $(6)$ & $(7)$ & $(8)$ & $(9)$ \\
\hline & Labor1 & Labor2 & Labor3 & Finance1 & Finance2 & Finance 3 & $\begin{array}{c}\text { AES } \\
\text { Labor }\end{array}$ & $\begin{array}{c}\text { AES } \\
\text { Finance }\end{array}$ & $\begin{array}{c}\text { AES } \\
\text { All }\end{array}$ \\
\hline & \multicolumn{9}{|c|}{ Age range: $26-29$ years } \\
\hline Economic shock & $\begin{array}{c}-0.026 \\
(0.026)\end{array}$ & $\begin{array}{c}-0.013 \\
(0.033)\end{array}$ & $\begin{array}{c}0.020 \\
(0.072)\end{array}$ & $\begin{array}{c}-0.076 \\
(0.047)\end{array}$ & $\begin{array}{c}-0.067 \\
(0.049)\end{array}$ & $\begin{array}{l}-0.056 \\
(0.050)\end{array}$ & $\begin{array}{c}-0.008 \\
(0.032)\end{array}$ & $\begin{array}{c}-0.067 \\
(0.042)\end{array}$ & $\begin{array}{c}-0.037 \\
(0.029)\end{array}$ \\
\hline $\begin{array}{l}\text { R-squared } \\
\mathrm{N}\end{array}$ & $\begin{array}{c}0.05 \\
15,541 \\
\end{array}$ & $\begin{array}{c}0.06 \\
12,730 \\
\end{array}$ & $\begin{array}{c}0.10 \\
2,834 \\
\end{array}$ & $\begin{array}{c}0.06 \\
6,459 \\
\end{array}$ & $\begin{array}{c}0.07 \\
6,464\end{array}$ & $\begin{array}{c}0.03 \\
6,411\end{array}$ & 10,368 & 6,445 & 8,407 \\
\hline $\mathrm{N}$ & \multicolumn{9}{|c|}{ Age range: $30-33$ years } \\
\hline Economic shock & $\begin{array}{c}-0.029 \\
(0.034)\end{array}$ & $\begin{array}{c}-0.034 \\
(0.038)\end{array}$ & $\begin{array}{c}0.049 \\
(0.099)\end{array}$ & $\begin{array}{c}-0.034 \\
(0.042)\end{array}$ & $\begin{array}{c}-0.031 \\
(0.041)\end{array}$ & $\begin{array}{c}0.008 \\
(0.064)\end{array}$ & $\begin{array}{c}-0.005 \\
(0.046)\end{array}$ & $\begin{array}{c}-0.019 \\
(0.029)\end{array}$ & $\begin{array}{c}-0.012 \\
(0.028)\end{array}$ \\
\hline \multirow[t]{2}{*}{$\mathrm{N}$} & $\begin{array}{c}0.05 \\
14,571 \\
\end{array}$ & $\begin{array}{c}0.06 \\
11,972 \\
\end{array}$ & $\begin{array}{c}0.10 \\
2,626\end{array}$ & $\begin{array}{c}0.06 \\
6,034 \\
\end{array}$ & $\begin{array}{c}0.07 \\
6,035 \\
\end{array}$ & $\begin{array}{c}0.03 \\
5,985 \\
\end{array}$ & 9,723 & 6,018 & 7,871 \\
\hline & \multicolumn{9}{|c|}{ Age range: $34-37$ years } \\
\hline Economic shock & $\begin{array}{c}0.018 \\
(0.045)\end{array}$ & $\begin{array}{c}0.006 \\
(0.052)\end{array}$ & $\begin{array}{c}0.027 \\
(0.094)\end{array}$ & $\begin{array}{c}0.090 \\
(0.055)\end{array}$ & $\begin{array}{c}0.071 \\
(0.054)\end{array}$ & $\begin{array}{c}0.061 \\
(0.056)\end{array}$ & $\begin{array}{c}0.020 \\
(0.043)\end{array}$ & $\begin{array}{c}0.074 * \\
(0.041)\end{array}$ & $\begin{array}{c}0.047 \\
(0.033)\end{array}$ \\
\hline $\begin{array}{l}\text { R-squared } \\
\mathrm{N}\end{array}$ & $\begin{array}{c}0.05 \\
13,111\end{array}$ & $\begin{array}{c}0.06 \\
10,849\end{array}$ & $\begin{array}{c}0.11 \\
2,287\end{array}$ & $\begin{array}{c}0.06 \\
5,369\end{array}$ & $\begin{array}{c}0.07 \\
5,370\end{array}$ & $\begin{array}{c}0.04 \\
5,319\end{array}$ & 8,749 & 5,353 & 7,051 \\
\hline $\mathrm{N}$ & \multicolumn{9}{|c|}{ Age range: $38-41$ years } \\
\hline Economic shock & $\begin{array}{c}0.040 \\
(0.038)\end{array}$ & $\begin{array}{c}0.023 \\
(0.042)\end{array}$ & $\begin{array}{c}0.109 \\
(0.096)\end{array}$ & $\begin{array}{l}-0.062 \\
(0.061)\end{array}$ & $\begin{array}{c}-0.018 \\
(0.057)\end{array}$ & $\begin{array}{c}0.031 \\
(0.052)\end{array}$ & $\begin{array}{c}0.055 \\
(0.039)\end{array}$ & $\begin{array}{c}-0.016 \\
(0.040)\end{array}$ & $\begin{array}{c}0.020 \\
(0.025)\end{array}$ \\
\hline R-squared & 0.05 & 0.06 & 0.13 & 0.07 & 0.08 & 0.04 & & & \\
\hline \multirow[t]{2}{*}{$\mathrm{N}$} & 11,260 & 9,354 & 1,934 & 4,648 & 4,643 & 4,593 & 7,516 & 4,628 & 6,072 \\
\hline & \multicolumn{9}{|c|}{ Age range: $42-45$ years } \\
\hline Economic shock & $\begin{array}{l}-0.046 \\
(0.046)\end{array}$ & $\begin{array}{c}0.032 \\
(0.050)\end{array}$ & $\begin{array}{l}-0.122 \\
(0.094)\end{array}$ & $\begin{array}{l}-0.017 \\
(0.066)\end{array}$ & $\begin{array}{c}-0.028 \\
(0.061)\end{array}$ & $\begin{array}{l}-0.047 \\
(0.057)\end{array}$ & $\begin{array}{c}-0.047 \\
(0.048)\end{array}$ & $\begin{array}{l}-0.030 \\
(0.044)\end{array}$ & $\begin{array}{c}-0.039 \\
(0.038)\end{array}$ \\
\hline R-squared & 0.05 & 0.07 & 0.14 & 0.08 & 0.08 & 0.06 & & & \\
\hline $\mathrm{N}$ & 9,281 & 7,765 & 1,539 & 3,783 & 3,779 & 3,735 & 6,195 & 3,766 & 4,980 \\
\hline
\end{tabular}


Table A13 (continued)

Other age ranges

\begin{tabular}{|c|c|c|c|c|c|c|c|c|c|}
\hline & $(1)$ & $(2)$ & $(3)$ & (4) & $(5)$ & $(6)$ & $(7)$ & $(8)$ & (9) \\
\hline & Labor1 & Labor2 & Labor3 & Finance1 & Finance2 & Finance 3 & $\begin{array}{c}\text { AES } \\
\text { Labor }\end{array}$ & $\begin{array}{c}\text { AES } \\
\text { Finance }\end{array}$ & $\begin{array}{c}\text { AES } \\
\text { All }\end{array}$ \\
\hline & \multicolumn{9}{|c|}{ Age range: $46-49$ years } \\
\hline Economic shock & $\begin{array}{c}0.046 \\
(0.041)\end{array}$ & $\begin{array}{l}0.099 * \\
(0.057)\end{array}$ & $\begin{array}{c}0.061 \\
(0.141)\end{array}$ & $\begin{array}{c}0.076 \\
(0.090)\end{array}$ & $\begin{array}{c}0.091 \\
(0.086)\end{array}$ & $\begin{array}{l}-0.002 \\
(0.059)\end{array}$ & $\begin{array}{c}0.072 \\
(0.055)\end{array}$ & $\begin{array}{c}0.055 \\
(0.060)\end{array}$ & $\begin{array}{c}0.063 \\
(0.049)\end{array}$ \\
\hline R-squared & 0.06 & 0.07 & 0.15 & 0.09 & 0.10 & 0.07 & & & \\
\hline \multirow[t]{2}{*}{$\mathrm{N}$} & 7,209 & 6,062 & 1,162 & 2,893 & 2,888 & 2,846 & 4,811 & 2,876 & 3,843 \\
\hline & \multicolumn{9}{|c|}{ Age range: $50-53$ years } \\
\hline Economic shock & $\begin{array}{c}-0.038 \\
(0.057)\end{array}$ & $\begin{array}{c}0.023 \\
(0.081)\end{array}$ & $\begin{array}{c}0.419 \\
(0.377)\end{array}$ & $\begin{array}{l}-0.243 \\
(0.146)\end{array}$ & $\begin{array}{c}-0.262 * * \\
(0.129)\end{array}$ & $\begin{array}{c}0.013 \\
(0.126)\end{array}$ & $\begin{array}{c}0.122 \\
(0.126)\end{array}$ & $\begin{array}{l}-0.15^{*} \\
(0.089)\end{array}$ & $\begin{array}{c}-0.014 \\
(0.090)\end{array}$ \\
\hline R-squared & 0.07 & 0.08 & 0.24 & 0.13 & 0.13 & 0.10 & & & \\
\hline $\mathrm{N}$ & 5,158 & 4,401 & 771 & 1,995 & 1,990 & 1,955 & 3,443 & 1,980 & 2,712 \\
\hline
\end{tabular}

Notes: The estimates $\alpha_{1}$ from estimating equation [1] are reported with standard errors clustered at the prefecture of residence at age 15 in parentheses. The number of observations reported for the AES in columns 7, 8, and 9 is the average number of observations in the regressions for the risk aversion for labor (columns 1-3), risk aversion for finance (columns 4-6), or all of them respectively. Significance levels: ${ }^{* * *} \mathrm{p}<0.01,{ }^{* *} \mathrm{p}<0.05,{ }^{*} \mathrm{p}<0.10$ 
Table A14

Results for women

\begin{tabular}{|c|c|c|c|c|c|c|c|c|c|}
\hline & $(1)$ & $(2)$ & (3) & (4) & $(5)$ & $(6)$ & (7) & $(8)$ & (9) \\
\hline & \multirow{2}{*}{ Labor1 } & \multirow{2}{*}{ Labor2 } & \multirow{2}{*}{ Labor3 } & \multirow{2}{*}{ Finance1 } & \multirow{2}{*}{ Finance2 } & \multirow{2}{*}{ Finance3 } & AES & AES & AES \\
\hline & & & & & & & Labor & Finance & All \\
\hline Economic shock & $\begin{array}{c}0.036 \\
(0.054)\end{array}$ & $\begin{array}{c}0.121^{* *} \\
(0.053)\end{array}$ & $\begin{array}{c}0.173 \\
(0.108)\end{array}$ & $\begin{array}{c}0.073 \\
(0.051)\end{array}$ & $\begin{array}{c}0.049 \\
(0.056)\end{array}$ & $\begin{array}{c}0.018 \\
(0.067)\end{array}$ & $\begin{array}{l}0.110^{*} \\
(0.057)\end{array}$ & $\begin{array}{c}0.047 \\
(0.049)\end{array}$ & $\begin{array}{c}0.079 * * \\
(0.036)\end{array}$ \\
\hline R-squared & 0.06 & 0.07 & 0.16 & 0.10 & 0.11 & 0.09 & & & \\
\hline $\mathrm{N}$ & 8,925 & 7,251 & 1,658 & 3,746 & 3,752 & 3,719 & 5,945 & 3,739 & 4,842 \\
\hline Basic demographics & X & X & X & X & X & X & X & X & X \\
\hline Income FE & $\mathrm{X}$ & $\mathrm{X}$ & $\mathrm{X}$ & $X$ & $X$ & $\mathrm{X}$ & $\mathrm{X}$ & $\mathrm{X}$ & $\mathrm{X}$ \\
\hline Year FE & $X$ & $X$ & $X$ & $X$ & $X$ & $\mathrm{X}$ & $X$ & $X$ & $X$ \\
\hline Age FE & $\mathrm{X}$ & $X$ & $\mathrm{X}$ & $X$ & $X$ & $\mathrm{X}$ & $X$ & $X$ & $X$ \\
\hline Pref. survey FE & $X$ & $\mathrm{X}$ & $X$ & $X$ & $X$ & $\mathrm{X}$ & $X$ & $\mathrm{X}$ & $X$ \\
\hline Pref. at $15 \mathrm{FE}$ & $X$ & $X$ & $\mathrm{X}$ & $X$ & $X$ & $\mathrm{X}$ & $X$ & $X$ & $X$ \\
\hline (Pref. at $15 \mathrm{FE})^{*}$ age & $\mathrm{X}$ & $\mathrm{X}$ & $\mathrm{X}$ & $\mathrm{X}$ & $\mathrm{X}$ & $\mathrm{X}$ & $\mathrm{X}$ & $\mathrm{X}$ & $\mathrm{X}$ \\
\hline
\end{tabular}

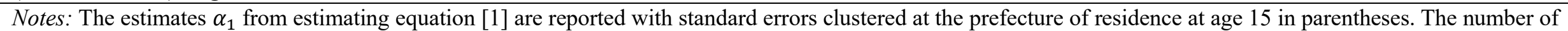

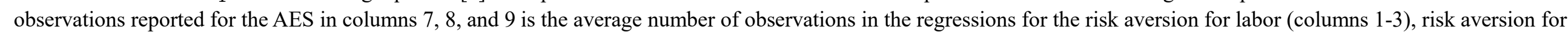
finance (columns 4-6), or all of them respectively. Significance levels: ${ }^{* * *} \mathrm{p}<0.01,{ }^{* *} \mathrm{p}<0.05,{ }^{*} \mathrm{p}<0.10$ 


\section{Appendix B: Data Appendix}

\section{Labor 1 (2005-2011)}

Which of the following two jobs do you prefer? Assume that the job contents are the same. The first is a job that gives you a 50-50 chance of doubling your monthly income and a 50-50 chance of cutting your monthly income by 30\%. The second is a job that will increase your monthly income by 5\%.

On one hand, individuals who accept the risky job then consider a choice between two jobs, one with even higher downside risk, as follows.

The first is a job that gives you a 50-50 chance of doubling your monthly income and a 50-50 chance of cut your monthly income by 50\%. The second is a job that will increase your monthly income by 5\%.

On the other hand, those who initially decline the risky job then consider a choice between two jobs, one with even lower downside risk.

The first is a job that gives you a 50-50 chance of doubling your monthly income and a 50-50 chance of cutting your monthly income by 10\%. The second is a job that will increase your monthly income by 5\%.

\section{Labor 2 (2007-2011)}

Which of the following two jobs do you prefer? Assume that the job contents are the same. The first is a job that gives you a 50-50 chance of increasing your monthly income by 60\% and a 50-50 chance of cutting your monthly income by $10 \%$. The second is a job that will increase your monthly income by 5\%.

On one hand, individuals who accept the risky job then consider a choice between two jobs, one with even higher downside risk, as follows.

The first is a job that gives you a 50-50 chance of increasing your monthly income by 30\% and a 50-50 chance of cut your monthly income by 10\%. The second is a job that will increase your monthly income by 5\%.

On the other hand, those who initially decline the risky job then consider a choice between two jobs, one with even lower downside risk.

The first is a job that gives you a 50-50 chance of increasing your monthly income by 200\% and a 50-50 chance of cutting your monthly income by 10\%. The second is a job that will increase your monthly income by 5\%.

\section{$\underline{\text { Labor } 3 \text { (2005-2006) }}$}

Which of the following two jobs do you prefer? Assume that the job contents are the same. The first is a job that gives you a 50-50 chance of increasing your monthly income by 30\% and a 50-50 chance of cutting your monthly income by $10 \%$. The second is a job that will increase your monthly income by 5\%.

On one hand, individuals who accept the risky job then consider a choice between two jobs, one with even higher downside risk, as follows. 
The first is a job that gives you a 50-50 chance of increasing your monthly income by 20\% and a 50-50 chance of cut your monthly income by $10 \%$. The second is a job that will increase your monthly income by $5 \%$.

On the other hand, those who initially decline the risky job then consider a choice between two jobs, one with even lower downside risk.

The first is a job that gives you a 50-50 chance of increasing your monthly income by 50\% and a 50-50 chance of cutting your monthly income by 10\%. The second is a job that will increase your monthly income by 5\%.

\section{Finance 1 (2005-2008)}

There is a lottery with a 1\% chance of winning JPY100,000 and nothing otherwise. Would you buy this lottery at a price of JPY200?

Individuals stating yes then consider higher price:

At which price would you like to buy? Choose one from 1-6 below.

\begin{tabular}{ll}
\hline 1 & JPY 300 \\
2 & JPY 400 \\
3 & JPY 600 \\
4 & JPY 1,000 \\
5 & JPY 2,000 \\
6 & More than JPY 2,000 \\
\hline
\end{tabular}

Individuals stating no then consider lower price:

At which price would you like to buy? Choose one from 1-6 below.

\begin{tabular}{ll}
\hline 1 & JPY 190 \\
2 & JPY 150 \\
3 & JPY 100 \\
4 & JPY 50 \\
5 & JPY 1 \\
\hline 6 & Don't Buy Even less than JPY 1 \\
\hline
\end{tabular}

\section{Finance 2 (2005-2008)}

There is a lottery with a 50\% chance of winning JPY2,000 or nothing otherwise. Would you buy this lottery at a price of JPY200?

Individuals stating yes then consider higher price:

At which price would you like to buy? Choose one from 1-6 below.

\begin{tabular}{ll}
\hline 1 & JPY 300 \\
2 & JPY 400 \\
3 & JPY 600 \\
4 & JPY 1,000 \\
5 & JPY 2,000 \\
6 & More than JPY 2,000 \\
\hline
\end{tabular}

Individuals stating no then consider lower price: At which price would you like to buy? Choose one from 1-6 below. 
1 JPY 190

2 JPY 150

3 JPY 100

4 JPY 50

5 JPY 1

6 Don't Buy Even less than JPY 1

Finance 3 (2005-2008)

There is a lottery with a 50\% chance of winning JPY2,000 or nothing otherwise. Suppose you possess one. Would you sell this lottery at a price of JPY200?

Individuals stating yes then consider lower price:

At which price would you like to sell? Choose one from 1-6 below.

1 JPY 190

2 JPY 150

3 JPY 100

4 JPY 50

5 JPY 1

6 Less than JPY 1

Individuals stating no then consider higher price:

At which price would you like to sell? Choose one from 1-6 below.

\begin{tabular}{ll}
\hline 1 & JPY 300 \\
2 & JPY 400 \\
3 & JPY 600 \\
4 & JPY 1,000 \\
5 & JPY 2,000 \\
6 & Don't Sell Even More than JPY 2,000 \\
\hline
\end{tabular}

